\title{
2. QUANTITATIVE CALCAREOUS NANNOFOSSIL BIOSTRATIGRAPHY OF UPPER OLIGOCENE TO MIDDLE MIOCENE SEDIMENT FROM ODP HOLE 667A AND MIDDLE MIOCENE SEDIMENT FROM DSDP SITE 574
}

\author{
Gunnar Olafsson ${ }^{2}$
}

\begin{abstract}
Detailed quantitative analyses of selected calcareous nannofossil species were used to determine the placement of zonal boundaries. In Hole $667 \mathrm{~A}$ in the equatorial Atlantic Ocean, Zones CP19 through CN5 were recognized, whereas at Site 574 in the equatorial Pacific Ocean, only the $\mathrm{CN} 4 / \mathrm{CN} 5$ boundary could be determined. Boundaries were identified by sharp rises and declines in abundance at the beginnings and ends, respectively, of index fossil ranges. The sharp rise in abundance at the beginning of the range of Triquetrorhabdulus rugosus provided a good datum level in both regions; the same is true for the sharp decline in abundance at the end of the range of Cyclicargolithus floridanus. The last occurrence of Helicosphaera ampliaperta was used to mark the CN3/CN4 boundary in Hole 667A, while at Site 574, H. ampliaperta was absent. The abundance pattern of Triquetrorhabdulus carinatus obtained from Hole 667A makes it impossible to observe a distinct disappearance level. Age/depth plots reveal uniform sedimentation rates at both sites during early Miocene times. At Site 667 in the Atlantic the mean sedimentation rate was $14.90 \mathrm{~m} / \mathrm{m}$.y., and at Site 574 in the Pacific it was $16.17 \mathrm{~m} / \mathrm{m} . \mathrm{y}$. during this same period. One new nannofossil species, Triquetrorhabdulus rioensis, is described; and one species, Triquetrorhabdulus serratus, is recombined.
\end{abstract}

\section{INTRODUCTION}

The most widely used Cenozoic calcareous nannofossil zonation schemes-Martini (1971) and Bukry $(1973,1975)$ and Okada and Bukry (1980) — are based mainly on the first (FO) and last (LO) occurrences (extinctions) of different nannofossil species.

By using quantitative methods combined with short sampling intervals, Backman (1986a, 1986b) showed that abundance patterns of species often reveal "tails" of strongly reduced presence below and above the consistent occurrence. These tails may represent either true, but reduced, productivity or postdepositional mixing of the sediment. Since these tails can vary in duration, the use of the absolute FO or LO of a species as a biostratigraphic marker can result in diachroneity when different geographic areas are compared. On the other hand, using sharp declines and rises in abundance as marker levels often gives more consistent information (see also Backman and Shackleton, 1983).

The aim of this study is to establish a quantitative nannofossil biostratigraphy for the lower Neogene of Ocean Drilling Program (ODP) Hole 667A. The results are compared with data from Deep Sea Drilling Project (DSDP) Site 574, partly gathered in this study and partly from Pujos (1985). Site 574 was chosen mainly because it is an equatorial site from a different ocean basin. This site should thus provide comparative information, particularly about the important biostratigraphic relationships between Cyclicargolithus floridanus, Sphenolithus heteromorphus, and Triquetrorhabdulus rugosus.

\section{MATERIALS AND METHODS}

Hole $667 \mathrm{~A}$ is located in the eastern equatorial Atlantic at $4^{\circ} 34.15^{\prime} \mathrm{N}$ and $21^{\circ} 54.68^{\prime} \mathrm{W}$ in water depths of $3535 \mathrm{~m}$ on the western margin of

\footnotetext{
${ }^{1}$ Ruddiman, W., Sarnthein, M., et al., 1989. Proc. ODP, Sci. Results, 108 College Station, TX (Ocean Drilling Program).

2 Department of Geology, University of Stockholm, S-106 91 Stockholm, Sweden.
}

the Sierra Leone Rise (Shipboard Scientific Party, 1988). Site 574 is located in the central equatorial Pacific high productivity area at $4^{\circ} 12.52^{\prime} \mathrm{N}$ and $139^{\circ} 19.81^{\prime} \mathrm{W}$ and in water depths of $4561 \mathrm{~m}$ (Shipboard Scientific Party, 1985). This study involves Cores 108-667A-18H down through - 36X (154.0-333.5 mbsf), and Cores 85-574-13H down through $-23 \mathrm{H}(108.0-167.0 \mathrm{mbsf})$. The cores from Hole $667 \mathrm{~A}$ were sampled at $30-\mathrm{cm}$ intervals, representing an average time interval of about 77,000 yr $(17,000-149,000 \mathrm{yr})$, whereas a $20-\mathrm{cm}$ sampling interval was used in Site 574, representing an average time interval of about $13,000 \mathrm{yr}(10,000-16,000 \mathrm{yr})$. The placoliths showed good preservation throughout the intervals investigated in both sections except in the top part of Hole 667A, where some dissolution could be seen. The discoasters and triquetrorhabdulids exhibited calcite overgrowth in both sections.

To avoid sorting the nannofossils, smear slides were made directly from core samples according to methods described by $\mathrm{Haq}$ and Lohmann (1976). During preparation some size sorting of nannofossils may occur; therefore, counts were made only in those fields of view where all size ranges of the assemblage were represented. Only light microscope techniques were used (plane-polarized and cross-polarized light). The counting methods used in this study are described and discussed by Backman and Shackleton (1983), and the zonation scheme adopted is that of Bukry (1973) and Okada and Bukry (1980).

Cores $108-667 \mathrm{~A}-20 \mathrm{H},-23 \mathrm{H}$, and $-29 \mathrm{X}$ are reported as being longer than $9.8 \mathrm{~m}$ (Shipboard Scientific Party, 1988). In this study, the void intervals in these cores are deleted in order to make the penetrated interval agree with the recovered sediment thickness. The sub-bottom depths within these cores are changed accordingly.

\section{RESULTS}

\section{Hole 667A: The Equatorial Atlantic Ocean}

In the virtual absence of Helicosphaera recta and Dictyococcites bisectus, Sphenolithus ciperoensis was counted in order to establish the top of Zone CP19. Figure 1 shows the abundance pattern of the upper part of the range of $S$. ciperoensis together with the cumulative percentages of all sphenoliths, which are composed primarily of Sphenolithus moriformis. In Core 108-667A-35X and in the lower part of Core 108-667A-34X, S. ciperoensis makes up about $10 \%$ of the total sphenolith assemblage. In the upper part of Core 108-667A-34X and up to its LO in Sample 108-667A-32X-4, 


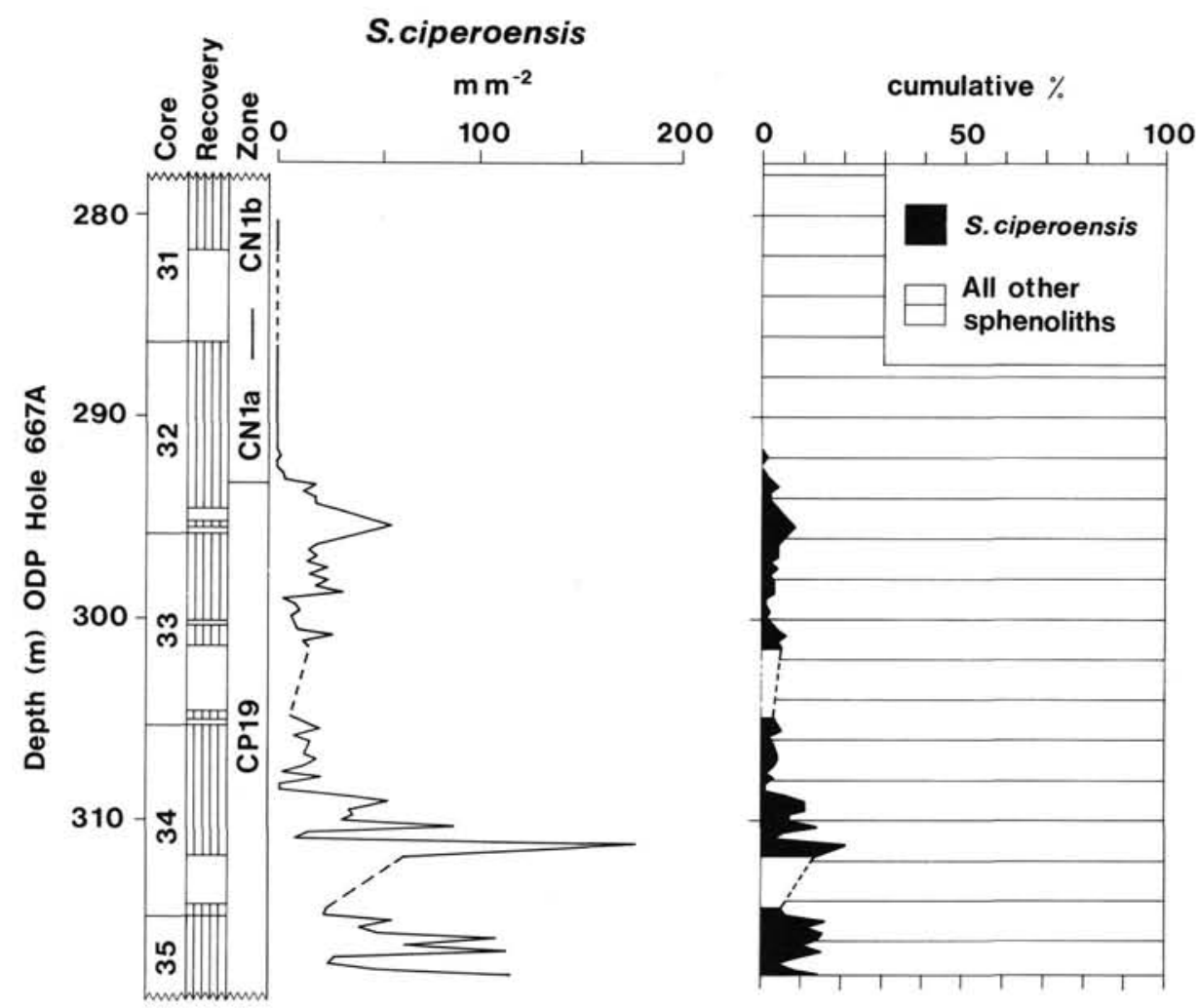

Figure 1. Plots of the abundance pattern and cumulative percentage of $S$. ciperoensis in Hole 667A. The LO of $S$. ciperoensis marks the top of Zone CP19.

$105-106 \mathrm{~cm}$ (291.85 mbsf), the abundance is less than $10 \%$ of the sphenolith assemblage. The abundance of $S$. ciperoensis varies considerably, but it is consistently present up to its LO. The top of Zone CP19 was placed at the decline in abundance between Samples 108-667A-32X-5, 105-106 cm, and 108$667 \mathrm{~A}-32 \mathrm{X}-5,75-66 \mathrm{~cm}$ (293.20 mbsf $\pm 0.15 \mathrm{~m})$.

The abundance patterns of the ranges of Sphenolithus belemnos and Sphenolithus heteromorphus together with the cumulative percentages of all sphenoliths are shown in Figure 2. Sphenolithus belemnos occurs in relatively high abundance, making up between $30 \%$ and $50 \%$ of the total sphenolith assemblage. The absolutely first specimens of $S$. belemnos were observed in Sample 108-667A-26X-2, 15-16 cm (230.95 mbsf). Poor core recovery in Core 108-667A-25X, however, prevented determination of the first distinct rise in abundance. It is tentatively placed between Samples 108-667A-26X-1, $45-46 \mathrm{~cm}$, and $-25 \mathrm{X}-4,47-48 \mathrm{~cm}(227.25 \mathrm{mbsf} \pm 2.50 \mathrm{~m})$, between which the abundance rises from 5 to 48 specimens $/ \mathrm{mm}^{2}$ (from $3 \%$ to $15 \%$ ). This rise in abundance was used to mark the top of Zone CN1c. The LO of $S$. belemnos is in Sample 108-667A-23H-7, 75-76 cm (208.0 mbsf). Just below its LO, between Samples 108-667A-24X-2, 15-16 cm, and 108-667A-24X-1, 105-106 cm (211.15 mbsf $\pm 0.15 \mathrm{~m})$, a sharp decline in the abundance from 84 to 0 specimens $/ \mathrm{mm}^{2}$ (from $18 \%$ to $0 \%$ ) can be seen. Further down, between Samples 108-667A-24X-2, 105-106 cm, and 109-667A-24X-3, 15-16 $\mathrm{cm},(212.85$ and $215.45 \mathrm{mbsf}$, respectively), a drop can be seen in the abundance and the cumulative percentage (from 177 to 15 specimens $/ \mathrm{mm}^{2}$, or from $30 \%$ to $5 \%$ ). This is due to a reduction in the number of $S$. belemnos in these samples while the abundance of other sphenoliths stays somewhat constant.
Sphenolithus heteromorphus is the dominant sphenolith throughout its range, showing a high but varying abundance (Fig. 2). The FO of $S$. heteromorphus is in Sample 108$667 \mathrm{~A}-24 \mathrm{X}-1,105-106 \mathrm{~cm}$ (211.35 mbsf). In the first $3 \mathrm{~m}$ of its range ( $211.35 \mathrm{mbsf}$ up to $208.0 \mathrm{mbsf})$, the abundance is low (less than $20 \%$ of the sphenoliths). At a depth of about $208 \mathrm{~m}$, the abundance rises sharply to a level of about $50 \%$. Generally, the abundance increases progressively throughout the range of $S$. heteromorphus up to about $80 \%$ prior to its LO in Sample 108-667A-18H-1, 135-136 cm (154.7 mbsf). The first distinct rise in abundance was used to mark the top of Zone CN2, which was placed between Samples 108-667A-23H-7, 75-76 cm, and 108-667A-23H-7, 45-46 cm (207.85 mbsf \pm $0.15 \mathrm{~m})$. Near the top of the range of $S$. heteromorphus, a distinct decline in abundance occurs. Sample 108-667A-18H$6,45-46 \mathrm{~cm}$ (161.25 mbsf), contained 630 specimens $/ \mathrm{mm}^{2}$, whereas in Sample 108-667A-18H-5, 75-76 cm (160.05 mbsf), the number was 10 specimens $/ \mathrm{mm}^{2}$. This final decline in the abundance of $S$. heteromorphus was used to mark the top of Zone CN4, which was placed between Samples 108-667A$18 \mathrm{H}-6,15-16 \mathrm{~cm}$, and 108-667A-18H-5, 105-106 cm (160.65 mbsf $\pm 0.30 \mathrm{~m})$. The isolated peak, which can be seen above the sharp decline in the cumulative percentage [Sample 108-667A$18 \mathrm{H}-3,135-136 \mathrm{~cm}(157.65 \mathrm{mbsf})]$, is probably an artifact caused by selective dissolution, assuming that the robust $S$. heteromorphus is less prone to dissolution than $S$. moriformis. The entire nannofossil assemblage shows considerable signs of dissolution, and the number of sphenoliths found in 20 fields of view in this sample is 18,6 of which are $S$. heteromorphus.

Cyclicargolithus floridanus was counted in order to determine its LO relative to the LO of $S$. heteromorphus and the 


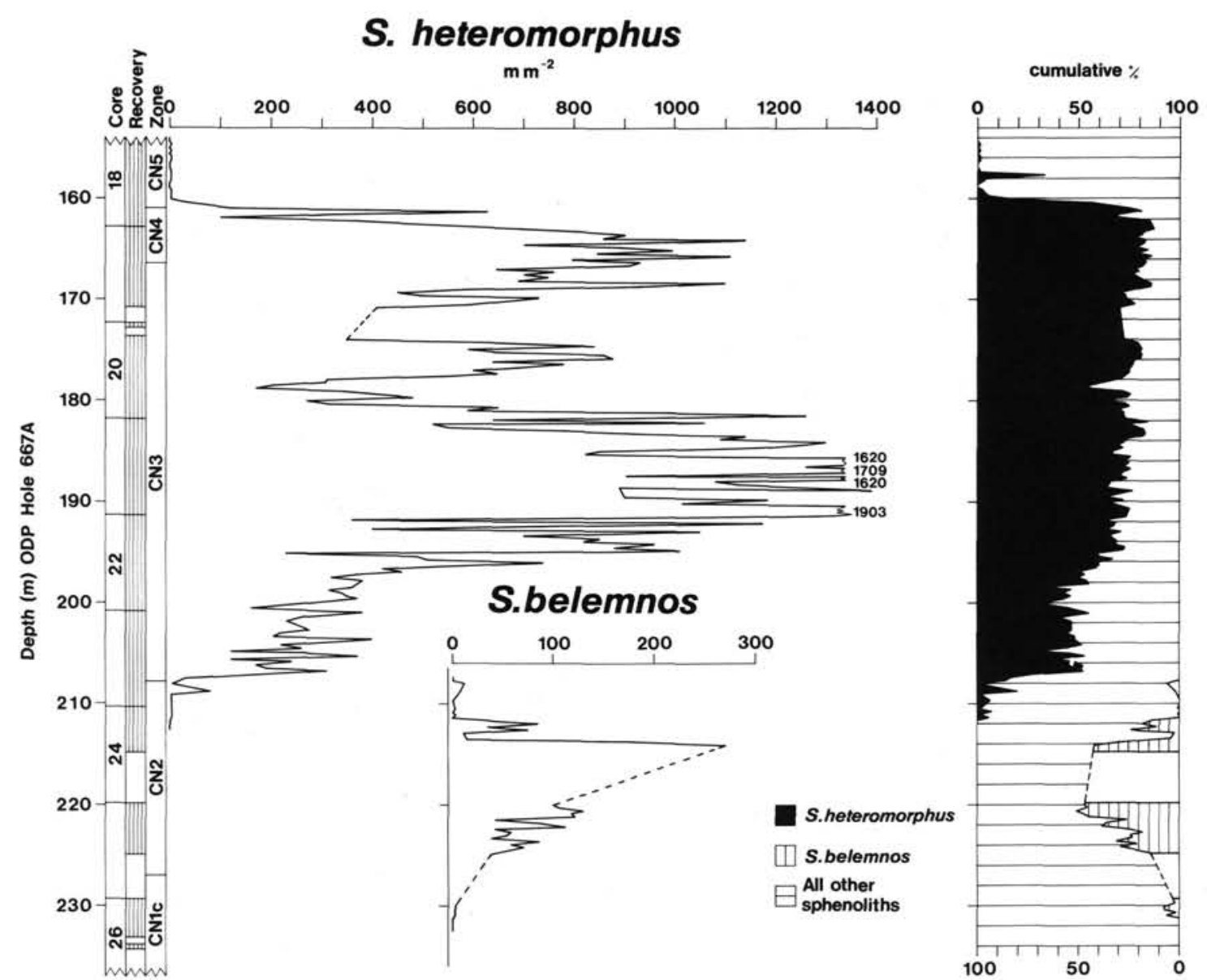

Figure 2. Plots of the abundance patterns and cumulative percentages of the ranges of $S$. belemnos and $S$. heteromorphus in Hole 667A. The FO of $S$. belemnos marks the top of Zone CN1c, and the FO of $S$. heteromorphus marks the top of Zone CN2. Note the scale difference $(\times 2)$ in the plot of the range of $S$. belemnos.

FO of Triquetrorhabdulus rugosus. Figure 3 shows the abundance pattern of the upper part of the range and the $\mathrm{LO}$ of $C$. floridanus. The abundance of $C$. floridanus is high, mostly over 100 specimens $/ \mathrm{mm}^{2}$, but it varies from 2 specimens $/ \mathrm{mm}^{2}$ in Sample 108-667A-19H-2, 105-106 cm (165.35 mbsf), to 350 specimens $/ \mathrm{mm}^{2}$ in Sample 108-667A-22H-2, 15-16 cm (192.95 mbsf). In the uppermost part of the range of $C$. floridanus, a sharp decline can be seen in abundance where it drops from 22 specimens $/ \mathrm{mm}^{2}$ in Sample 108-667A-18H-4, 45-46 cm (158.25 mbsf), to 1 specimen $/ \mathrm{mm}^{2}$ in Sample 108-667A-18H-4, 15-16 $\mathrm{cm}$ (157.95 mbsf). The last specimens of $C$. floridanus were observed in Sample 108-667A-18H-2, 15-16 cm (154.95 mbsf). The strongly variable abundance of $C$. floridanus seems to contain a high-frequency signal that possibly may be related to orbital periodicities, although the present sampling interval is too wide to reveal such a link.

The abundance pattern of the range of Helicosphaera ampliaperta is shown in Figure 4. The FO was observed in Sample 108-667A-23H-7, 75-76 cm (208.0 mbsf). Helicosphaera ampliaperta occurs inconsistently and in low and varying numbers throughout its range, never exceeding 40 specimens $/ \mathrm{mm}^{2}$. The LO was observed in Sample 108-667A$19 \mathrm{H}-3,75-76 \mathrm{~cm}$ (166.55 mbsf). No sharp decline was observed at the end of the range of $H$. ampliaperta, so the LO was used to mark the top of Zone $\mathrm{CN} 3$, in accordance with Bukry's (1973) original definition of the top of the H. ampliaperta Zone. This boundary was placed between Samples
108-667A-19H, 45-46 cm, and 108-667A-19H, 75-76 cm $(166.40 \mathrm{mbsf} \pm 0.15 \mathrm{~m})$. Helicosphaera ampliaperta was not observed in the equatorial Pacific Site 574 according to Pujos (1985).

The abundance pattern of the lower part of the range of Triquetrorhabdulus carinatus is shown in Figure 5. The lowermost specimen of $T$. carinatus was observed in Sample 108-667A-36X-3, 15-16 cm (327.2 mbsf). Poor core recovery in the lower parts of Cores $108-667 \mathrm{~A}-36 \mathrm{X}$ up through $-33 \mathrm{X}$ made it difficult to notice any distinct rise in abundance at the beginning of the range of $T$. carinatus. Instead, the abundance rises gradually from less than 5 specimens $/ \mathrm{mm}^{2}$ in Core $108-667 \mathrm{~A}-36 \mathrm{X}$ up to about 60 specimens $/ \mathrm{mm}^{2}$ in Core 108 667A-33X. A sharp rise in abundance, from 60 to 220 specimens $/ \mathrm{mm}^{2}$, can be seen between Samples 108-667A$33 \mathrm{X}-1,45-46 \mathrm{~cm}$ (296.25 mbsf), and 108-667A-32X-6, 72-73 $\mathrm{cm}$ (294.55 mbsf). From there, abundance declines gradually up to the top of Core 108-667A-30X, where a sharp rise from about 40 to over 160 specimens $/ \mathrm{mm}^{2}$ can be seen [Samples 108-667A-30X-1, 45-46 cm (267.65 mbsf), and 108-667A$29 \mathrm{X}-6,130-131 \mathrm{~cm}$ (266.25 mbsf), respectively]. The abundance is high from the top of Core 108-667A-30X up through Core 108-667A-28X, where it declines sharply from 150 to 50 specimens $/ \mathrm{mm}^{2}$ between Samples 108-667A-28X-3, 45-46 $\mathrm{cm}$, and 108-667A-28X-3, 15-16 cm (251.60 mbsf $\pm 0.15 \mathrm{~m})$. Poor core recovery in Cores 108-667A-27X up through -24X, combined with low and sporadic occurrences throughout the 


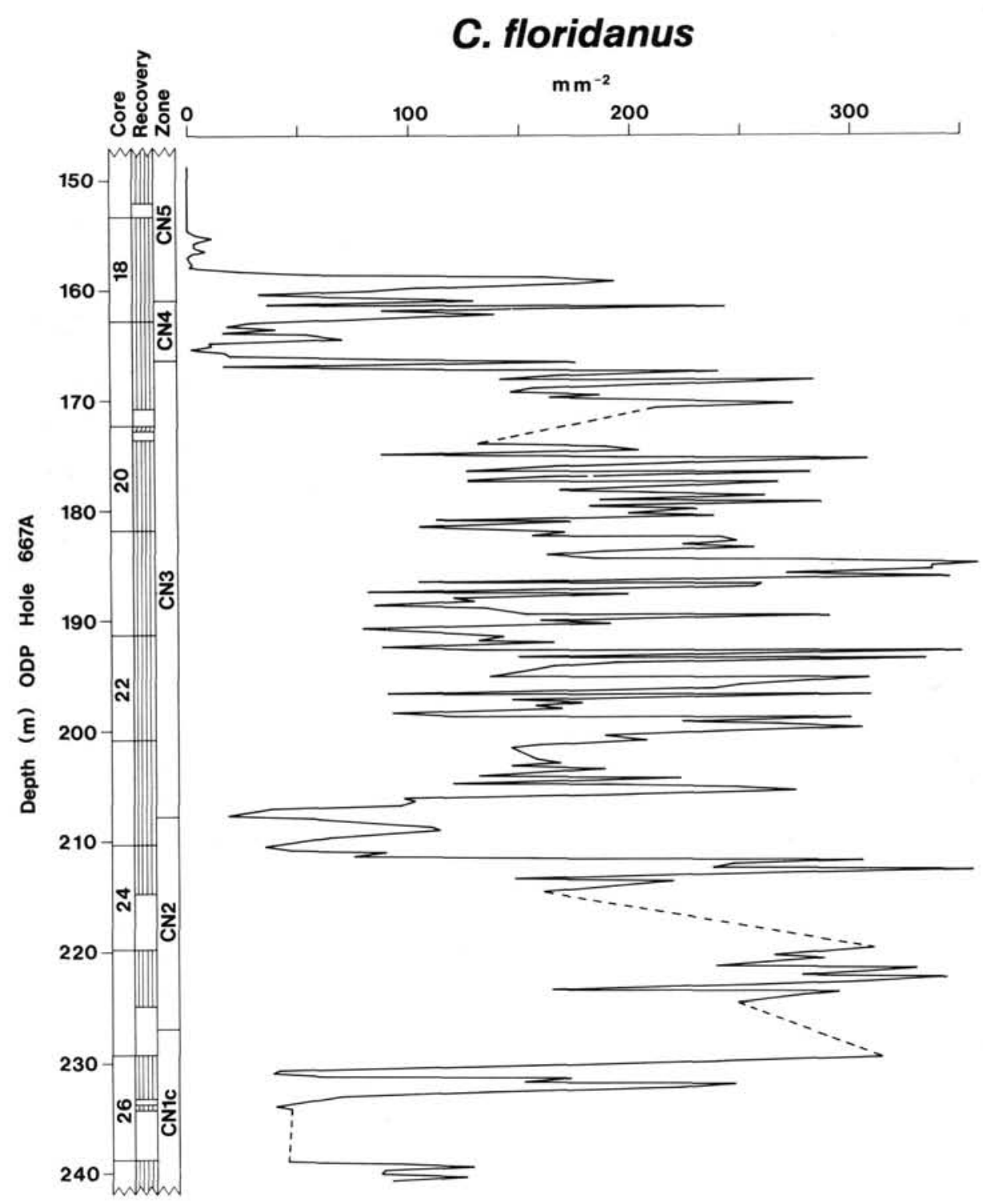

Figure 3. Plots of the abundance pattern of the upper part of the range and LO of $C$. floridanus in Hole 667A.

remaining part of the investigated interval, prevented detection of any final decline in abundance of $T$. carinatus. Between Cores $108-667 \mathrm{~A}-28 \mathrm{X}$ and $-23 \mathrm{H}$ the abundance is 0 to 40 specimens $/ \mathrm{mm}^{2}$. Throughout the remainder of the interval investigated, the abundance is less than 10 specimens $/ \mathrm{mm}^{2}$, showing abundance peaks at about 205, 192, and 177 mbsf. The uppermost specimens of $T$. carinatus were observed in Sample 108-667A-18H-2, 135-136 cm (156.15 mbsf).

The abundance patterns of Triquetrorhabdulus milowii, Triquetrorhabdulus serratus, and T. carinatus are shown in Figure 6. Triquetrorhabdulus milowii was not observed below Sample 108-667A-28X-3, 45-46 cm (251.8 mbsf), and it occurs sporadically in low abundances (never exceeding 40 specimens $/ \mathrm{mm}^{2}$ ) throughout the interval investigated. The lowermost specimens of $T$. serratus were observed in Sample 108-667A-27X-3, 45-46 $\mathrm{cm}$ (242.25 mbsf). This rather distinct FO was used to mark the top of Zone CN1b (see Bukry, 1973), which was placed between Samples 108-667A-27X-3, 75-76 cm, and 108-667A-27X-3, $45-46 \mathrm{~cm}$ ( $242.40 \mathrm{mbsf} \pm 0.15 \mathrm{~m})$. Triquetrorhabdulus serratus occurs sporadically throughout the investigated interval, with its highest abundance (about 80 specimens $/ \mathrm{mm}^{2}$ ) in Sample 108667A-18H-3, 15-16 cm (156.45 mbsf).

Figure 7 shows the abundance patterns of the lowermost part of the ranges of Triquetrorhabdulus rugosus and $T$. rioensis. The FO of T. rugosus is in Sample 108-667A-19H-3, 15-16 cm (167 mbsf), and the FO of $T$. rioensis is in Sample 108-667A-19H-2, $105-106 \mathrm{~cm}$ (165.35 mbsf). Both species show a sharp increase in abundance (from $10 \%$ to $40 \%$ of the triquetrorhabdulid assemblage) between Samples 108-667A-18H-4, 15-16 cm, and 108$667 \mathrm{~A}-18 \mathrm{H}-3,135-136 \mathrm{~cm}$ (157.80 mbsf $\pm 0.15 \mathrm{~m})$.

The cumulative percentages of the triquetrorhabdulids in Cores 108-667A-18H and $-19 \mathrm{H}$ are shown in Figure 8. In these cores, $T$. milowii and $T$. serratus dominate the triquetrorhabdulid assemblage. A peak interval of $T$. milowï at about the FO of $T$. rugosus was also observed in Hole 574. At the top of the investigated interval, $T$. nugosus and $T$. rioensis become dominant.

\section{Site 574: The Equatorial Pacific Ocean}

Figure 9 shows the abundance pattern of the upper part of the range of $S$. heteromorphus together with the cumulative 


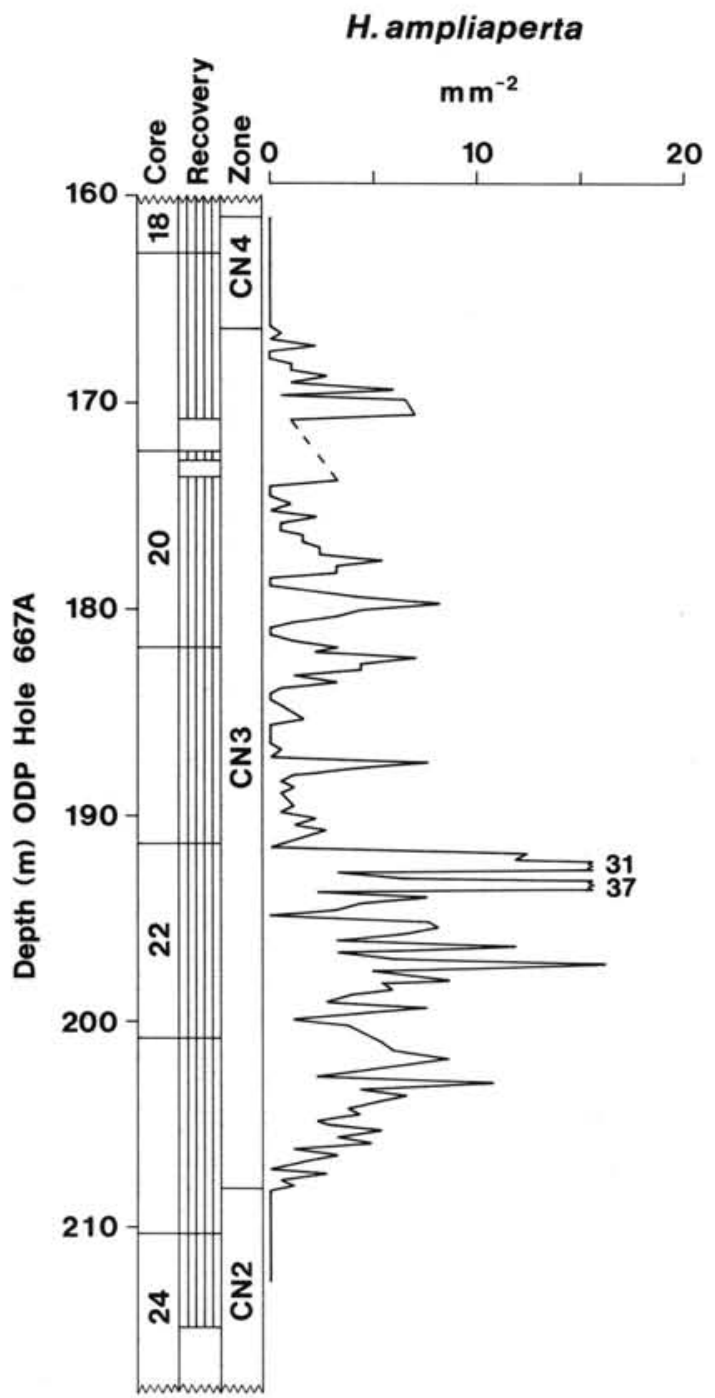

Figure 4. Plots of the abundance pattern of the range of $H$. ampliaperta in Hole 667A. The LO of $H$. ampliaperta marks the top of Zone CN3.

percentages of all sphenoliths. Sphenolithus heteromorphus occurs consistently from the bottom of the investigated interval up through Core $85-574-20 \mathrm{H}$, where its LO was observed in Sample 85-574-20H-2, 49-50 cm (149.6 mbsf). It shows a high and varying abundance in Site 574 in the equatorial Pacific, similar to the pattern obtained from Hole 667A in the equatorial Atlantic, comprising over $50 \%$ of the sphenolith assemblages. At the end of the consistent occurrence of $S$. heteromorphus, a sharp decline in abundance is observed, from about $50 \%$ in Sample 85-574-20H-3, 39-40 cm (151.0 mbsf), to $0 \%$ in Sample 85-574-20H-2, 29-30 cm (149.4 mbsf). This sharp decline is coincident with the LO of $S$. heteromorphus and was used to mark the $\mathrm{CN} 4 / \mathrm{CN} 5$ boundary, which was placed between Samples 85-574-20H-2, 49-50 cm, and $85-574-20 \mathrm{H}-2,29-30 \mathrm{~cm}(149.50 \mathrm{mbsf} \pm 0.10 \mathrm{~m})$. The isolated reappearances of $S$. heteromorphus in Cores $85-574-16 \mathrm{H}$ and $-14 \mathrm{H}$ are most likely due to reworking.

The abundance pattern of the upper part of the range of $C$. floridanus is shown in Figure 10. Cyclicargolithus floridanus is less abundant at Site 574 in the equatorial Pacific than in Hole 667 A in the equatorial Atlantic. It occurs consistently from the bottom of the investigated interval up to the top of Core

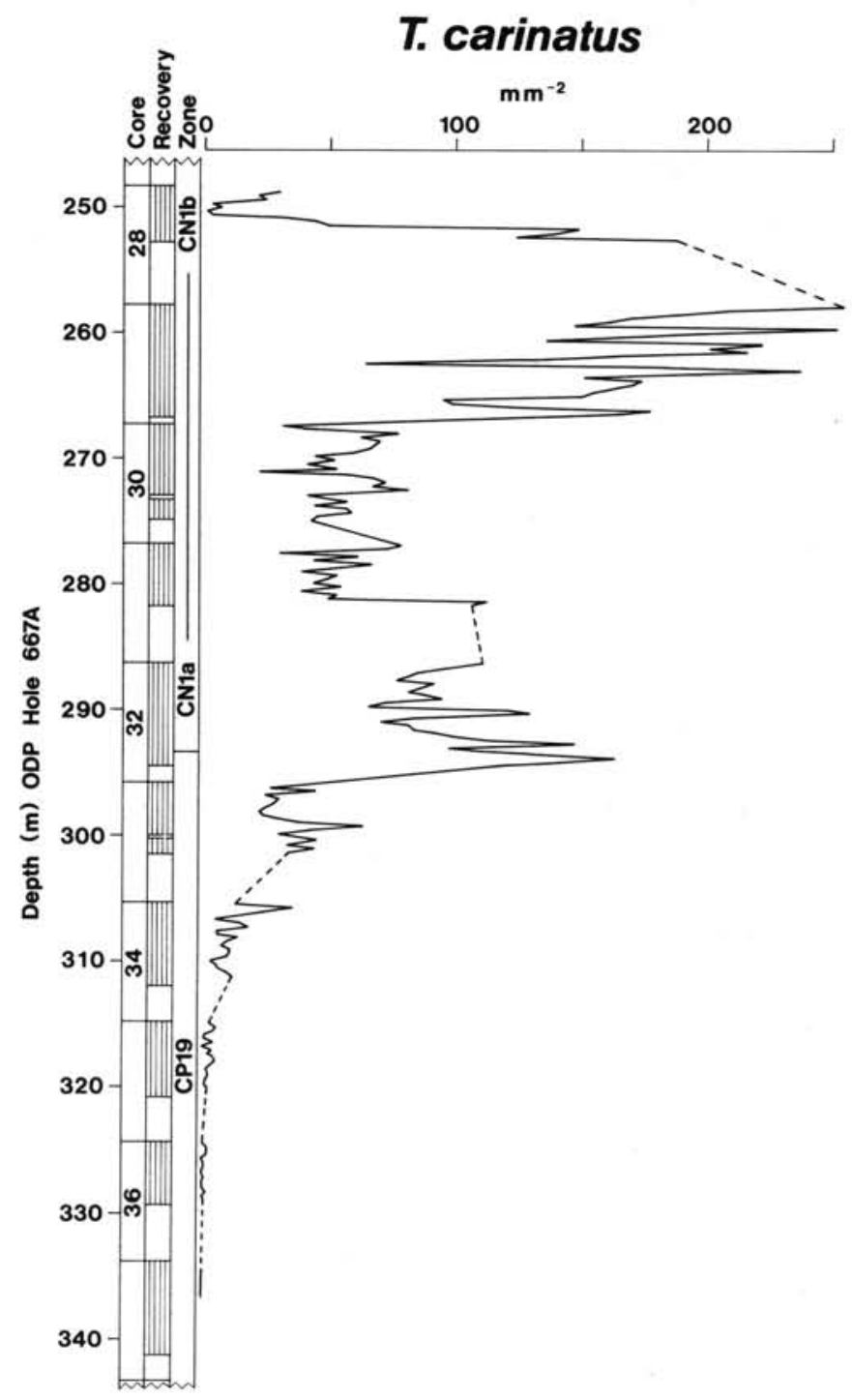

Figure 5. Plots of the abundance pattern of the lower part of the range of $T$. carinatus in Hole 667A. See Figure 6 for the upper part of the range of $T$. carinatus. Note the sharp decline in abundance in the upper part of Core 108-667A-28X.

85-574-19H. Similar variations are seen in the abundance of C. floridanus in both basins, although the decline in abundance is more gradual in the Pacific. Despite this, a final decline in abundance, which coincides with the LO of $C$. floridanus is observed between Samples 85-574-19H-1, 39-40 $\mathrm{cm}$, and $85-574-19 \mathrm{H}-1,19-20 \mathrm{~cm}(142.90 \mathrm{mbsf} \pm 0.10 \mathrm{~m})$. The isolated reoccurrences in Cores $85-574-16 \mathrm{H}$ and $-14 \mathrm{H}$ coincide exactly with those of $S$. heteromorphus, emphasizing the reworking aspect of the sediment.

The abundance patterns of $T$. milowii, $T$. serratus, $T$. rugosus, and $T$. rioensis are shown in Figure 11. Their abundances are low, although $T$. serratus is generally dominant. The first specimens of $T$. rugosus were observed in Sample 85-574-19H-3, 99-100 cm (146.6 mbsf), while the first specimens of $T$. rioensis were observed in Sample 85-574$18 \mathrm{H}-3,119-121 \mathrm{~cm}$ (141.8 mbsf). At Site 574, these two species do not show the same sharp increase in abundance as in Hole 667A, although $T$. rugosus seems to have a slightly earlier appearance than $T$. rioensis, as in Hole 667A. The cumulative percentages (Fig. 12) of these species, together 


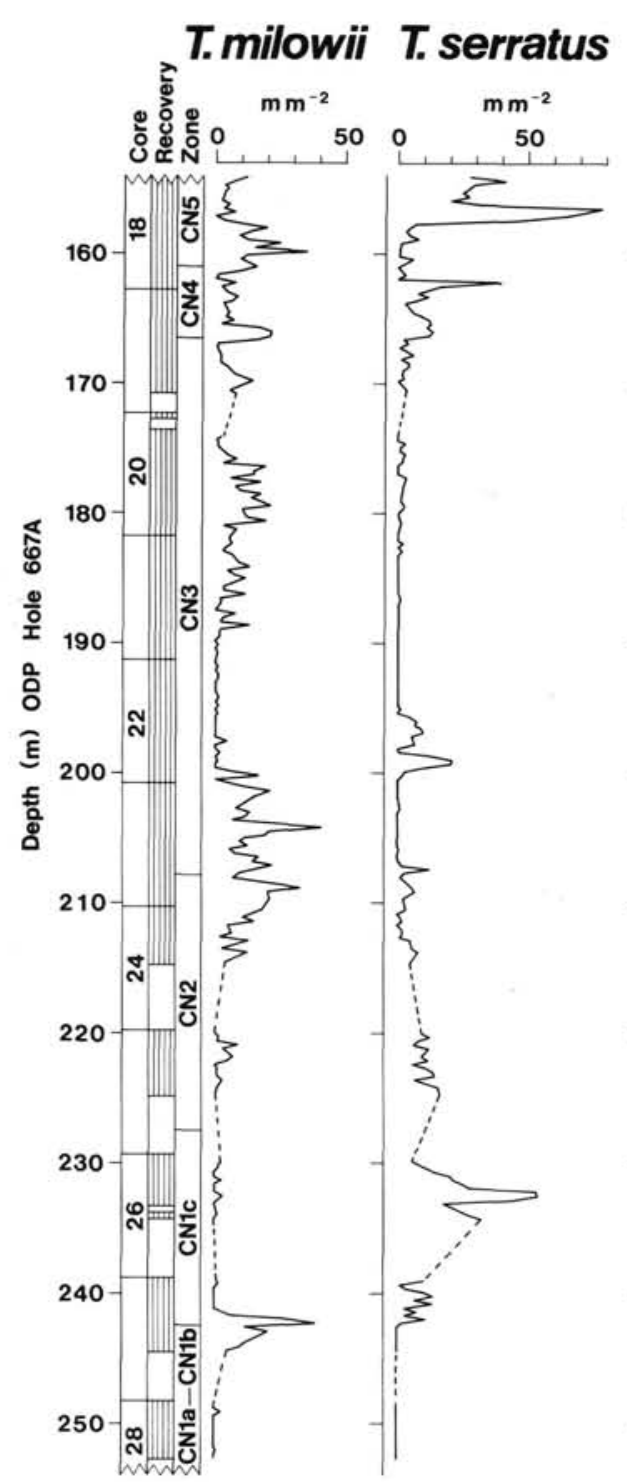

T.carinatus
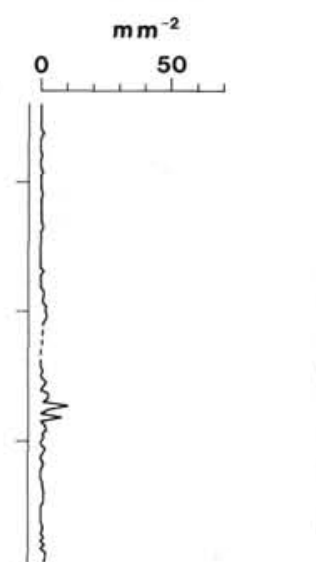

Figure 6. Plots of the abundance patterns of the lower part of the ranges of $T$. milowii and $T$. serratus and the upper part of the range of T. carinatus in Hole 667A. The FO of T. serratus marks the top of Zone CN1b (see Bukry, 1973). See Figure 5 for the lower part of the range of $T$. carinatus.

with $T$. milowii and $T$. serratus, reveal a pattern similar to the one observed in Hole 667A. In Core 85-574-19H, T. serratus is the dominant species up to $141.9 \mathrm{mbsf}$, where an increase in the abundance of $T$. rugosus and $T$. rioensis is observed.

\section{AGE ESTIMATES AND SEDIMENTATION RATES}

The age/depth plots for ODP Hole 667A and DSDP Site 574 are shown in Figures 13 and 14, respectively. For Hole 667A, the plot is based on nannofossil events gathered in this study. The plot for Site 574 is partly based on nannofossil events gathered in this study and partly on the results of Pujos (1985). The nannofossil events used for constructing the age/depth plots are summarized in Tables 1 and 2 together with their age estimates while the resulting sedimentation rates are summarized in Table 3 . The age estimates for events 3,4 , and 5 were obtained by correlating the nannofossil events at DSDP Site 608 (Takayama and Sato, 1987) to the magnetostratigraphy of the same site (Clement and Robinson, 1987); the age estimate

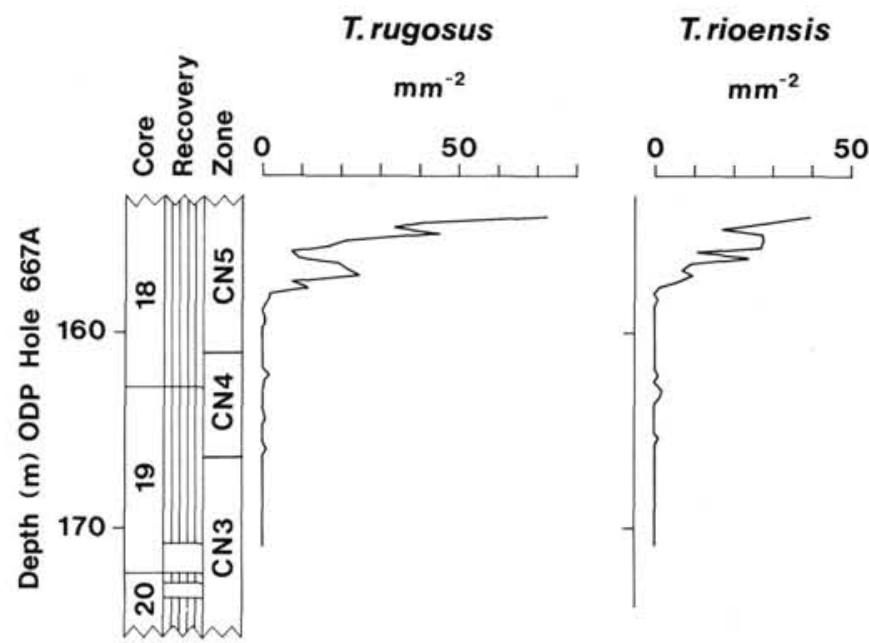

Figure 7. Plots of the abundance patterns of the lower part of the ranges of $T$. rugosus and T. rioensis in Hole 667A.

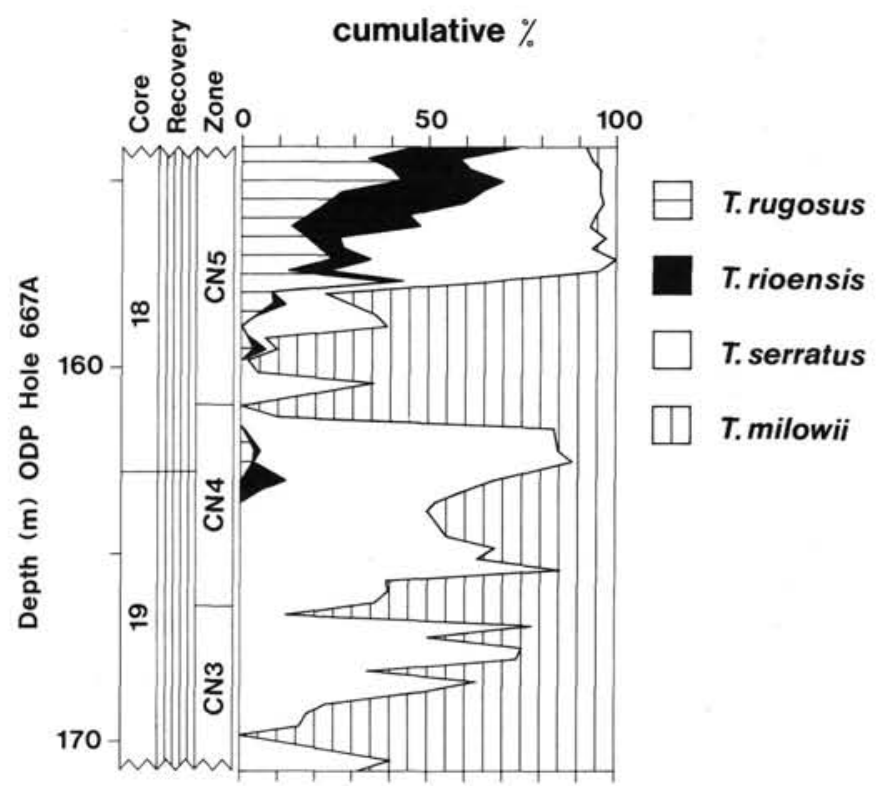

Figure 8. Plots of the cumulative percentages of T. rugosus, T. rioensis, T. serratus, and T. milowii in Hole 667A.

for event 10, however, is from Berggren et al. (1985). The estimates should be regarded as preliminary, since they are based on events that have not been analyzed with the same methods as in this study.

The ages assigned to the rise in abundance of $T$. rugosus (event 1) and the final decline in abundance of $C$. floridanus (event 2) were found by extrapolation from events 3 and 5 at Site 574. The range chart of Takayama and Sato (1987) indicates that $S$. belemnos was observed only as "trace" in the early part of its range at Site 608 . Since the true nature of this "trace" could not be revealed from the range charts alone and because of the uncertainty $( \pm 2.50 \mathrm{~m})$ in the determination of the first rise in abundance of $S$. belemnos in Hole 667A, the age of this event was estimated by interpolation between events 5 and 10 . The resulting age is $19.96 \pm 0.20 \mathrm{Ma}$ in Hole $667 \mathrm{~A}$ and $19.46 \pm 0.04 \mathrm{Ma}$ at Site 574 . The difference in these estimates is probably caused by the different methods used for determining the datum plane in Hole $667 \mathrm{~A}$ and at Site 574 


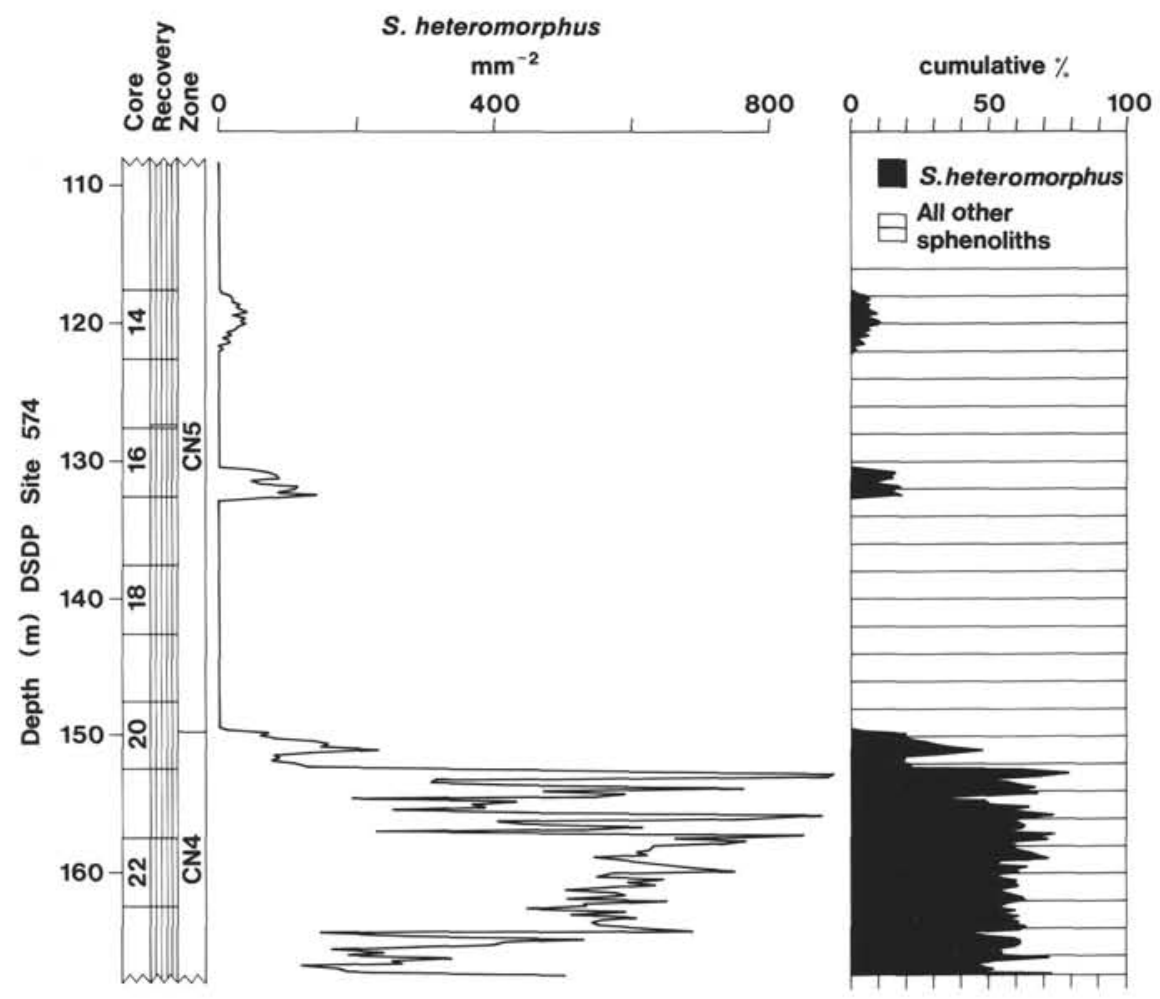

Figure 9. Plots of the abundance patterns of the upper part of the range of $S$. heteromorphus and the cumulative percentages of all sphenoliths at Site 574. The sharp decline in the abundance of $S$. heteromorphus marks the top of Zone CN4. The reappearance of $S$. heteromorphus in Cores $85-574-14 \mathrm{H}$ and $-16 \mathrm{H}$ is probably due to reworking.

(Pujos, 1985), and by the long interval between the control points used for interpolation.

In Hole 667A the sedimentation rate is relatively low (3.74, 4.90 , and $2.02 \mathrm{~m} / \mathrm{m} . \mathrm{y}$.) from the rise in abundance of $T$. rugosus (event 1 ) down to the disappearance of $H$. ampliaperta (event 4). Below event 4 , the sedimentation rate is higher $(17.20$ and $12.59 \mathrm{~m} / \mathrm{m} . \mathrm{y}$.) down to the final decline in abundance of $S$. ciperoensis (event 10). The mean sedimentation rate for this lower interval, assigned to early Miocene, is $14.90 \mathrm{~m} / \mathrm{m} . \mathrm{y}$. At Site 574 , the sedimentation rate is relatively high (12.71 m/m.y.) from event 1 down to the FO (Pujos, 1985) of $S$. heteromorphus (event 5). For the rest of the interval the sedimentation rate is $19.62 \mathrm{~m} / \mathrm{m} . \mathrm{y}$. The mean sedimentation rate for the whole interval is $16.17 \mathrm{~m} / \mathrm{m} . \mathrm{y}$.

\section{DISCUSSION}

The zonal boundaries of Bukry (1973) and Okada and Bukry (1980) were identified from the uppermost Oligocene to the middle Miocene in Hole 667A and were determined with a precision of $\pm 0.15 \mathrm{~m}$, with the exception of the $\mathrm{CN} 1 / \mathrm{CN} 2$ boundary $( \pm 2.50 \mathrm{~m})$ and the $\mathrm{CN} 4 / \mathrm{CN} 5$ boundary $( \pm 0.30 \mathrm{~m})$. At DSDP Site 574 only the CN4/CN5 boundary could be determined. Tables 1 and 2 summarize the zonal boundaries together with their age assignments.

The final decline in the abundance of $S$. ciperoensis was used to mark the CP19/CN1a boundary in Hole 667A. It is distinct and a good biostratigraphic marker for this region. The age assigned to this event is $25.2 \mathrm{Ma}$ (Berggren et al., 1985).

Because of the poor core recovery in Cores 108-667A-27X up through $-24 \mathrm{X}$ and the sporadic occurrence of $T$. carinatus up through the remaining part of the interval investigated, it is virtually impossible to determine a distinct disappearance level of this species. The sharp decline in the abundance of $T$. carinatus (event 9), which can be seen at $251 \mathrm{mbsf}$, is probably a better biostratigraphic indicator than the LO, which was observed at 156 mbsf. A similar drop in abundance, followed by a tail of low abundance, has been reported from the mid-latitude North Atlantic Ocean at DSDP Site 563 (Parker et al., 1985). By interpolation, the age of this decline in abundance was estimated to be $21.89 \pm 0.01 \mathrm{Ma}$. It should be stressed that event 9 should not be regarded as either the final decline in abundance or the LO of $T$. carinatus, an event that must be considered to be of a younger age. Using the depth data of Pujos (1985) for the LO of T. carinatus at Site 574, and interpolating between the final decline in abundance of $S$. ciperoensis and the first rise in abundance of $S$. heteromorphus results in an age of $19.23 \pm 0.3 \mathrm{Ma}$.

Since Discoaster druggii was not determined, mainly because of overgrowth problems, the FO of $T$. serratus was used to mark the CN1b/CN1c boundary (see Bukry, 1973). From the age/depth plots in Figures 13 and 14, the age of this boundary was estimated by interpolation. In Hole 667A (Fig. 13 ) the resulting age is $21.16 \pm 0.01 \mathrm{Ma}$. Based on the results of Pujos (1985), the age obtained is $21.73 \pm 0.04 \mathrm{Ma}$ at Site 574 (Fig. 14). These different age estimates are probably the result of different methods used to determine the FO of $T$. serratus as well as the long distance between the control points used for interpolation.

The $\mathrm{CN} 1 / \mathrm{CN} 2$ boundary was marked by a rise in the abundance of $S$. belemnos. Poor core recovery in Hole 667A made it difficult to determine this level precisely, which is reflected by a large uncertainty $(227.30$ mbsf $\pm 2.50 \mathrm{~m})$. By interpolation, the age of this event was estimated to be 19.96 


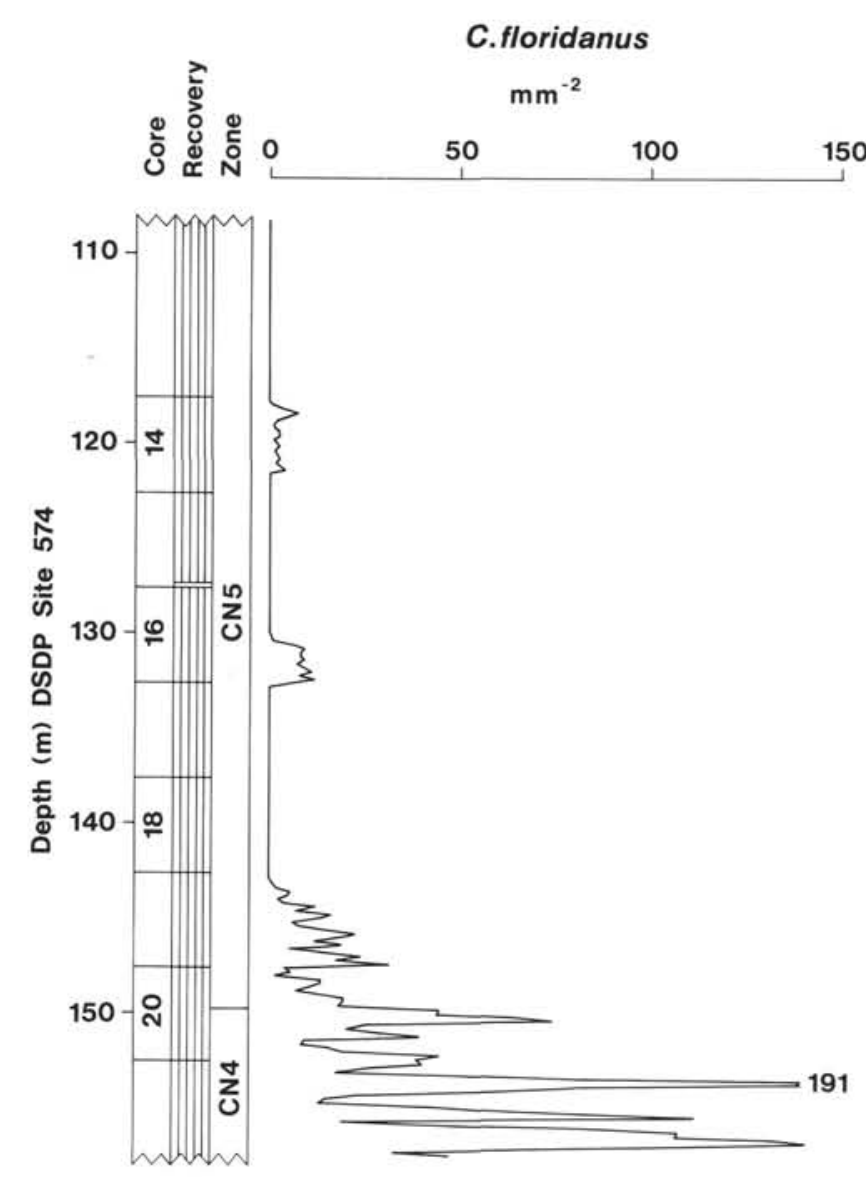

Figure 10. Plots of the abundance pattern of the upper part of the range of $C$. floridanus at Site 574. The reappearance of $C$. floridanus in Cores $85-574-14 \mathrm{H}$ and $-16 \mathrm{H}$ is probably due to reworking, as with $S$. heteromorphus (see Fig. 9).

$\pm 0.20 \mathrm{Ma}$ in Hole $667 \mathrm{~A}$, while at Site 574 the resulting age estimate is $19.46 \pm 0.04 \mathrm{Ma}$, based on depth data from Pujos (1985).

Bukry (1973) used the LO of $S$. belemnos and the FO of $S$. heteromorphus to mark the $\mathrm{CN} 2 / \mathrm{CN} 3$ boundary. Bukry (1972) reported a co-occurrence of these two species at DSDP Site 140 in the Atlantic Ocean, but preferred to use the cosmopolitan S. heteromorphus as a marker (Bukry 1972, 1973). Cooccurrence has also been reported from DSDP Site 610 in the North Atlantic Ocean (Takayama and Sato, 1987) and in the equatorial Pacific Ocean (Pujos, 1985). At DSDP Site 608 in the North Atlantic Ocean these two species do not occur together (Takayama and Sato, 1987). In ODP Hole 667A $S$. heteromorphus is present in much higher abundance than $S$. belemnos. In this study the sharp rise in the abundance of $S$. heteromorphus was used to mark the $\mathrm{CN} 2 / \mathrm{CN} 3$ boundary. The age estimate for this event is $18.42 \pm 0.15 \mathrm{Ma}$, as derived from DSDP Site 608 (Takayama and Sato, 1987; Clement and Robinson, 1987).

If Bukry's (1973) original definition of the CN3/CN4 boundary is retained, as marked by the LO of $H$. ampliaperta, it is possible to recognize this boundary in Hole 667A. Using the FO of Calcidiscus macintyrei for the purpose of defining the $\mathrm{CN} 3 / \mathrm{CN} 4$ boundary (Bukry, 1975, 1978) would give rise to problems. A careful scanning of samples from Core 108667A-24X revealed the presence of $C$. macintyrei below the FO of $S$. heteromorphus (CN2/CN3 boundary). The same relationship has been reported from other sections ([e.g.,
DSDP Site 608 [Takayama and Sato, 1987] and DSDP Site 588 [Lohman, 1986]). Thus, the FO of $C$. macintyrei cannot be used to define the $\mathrm{CN} 3 / \mathrm{CN} 4$ boundary, while the original definition of Bukry (1973) seems valid, at least in Hole 667A. The age estimate obtained for this event is $16.01 \pm 0.12 \mathrm{Ma}$ as derived from DSDP Site 608 (Takayama and Sato, 1987; Clement and Robinson, 1987). Because of the absence of $H$. ampliaperta at Site 574 (Pujos, 1985), the CN3/CN4 boundary could not be determined in that section.

The $\mathrm{CN} 4 / \mathrm{CN} 5$ boundary was marked by a sharp decline in the abundance of $S$. heteromorphus. This is probably a better stratigraphic marker than the absolute LO, in Hole 667A and at Site 574. In Hole 667A a tail of strongly reduced presence can be observed above the sharp decline in abundance having a duration of about 1.2 m.y. No such tail can be seen in Site 574 so in order to correlate these two sections, the sharp decline in abundance provides the best instrument. The age estimated for this boundary is $13.17 \pm 0.03 \mathrm{Ma}$, as derived from DSDP Site 608 (Takayama and Sato, 1987; Clement and Robinson, 1987).

The final decline in the abundance of $C$. floridanus is quite distinct at Site 574 and in Hole $667 \mathrm{~A}$ and provides a good datum level for both regions. The age assigned to this event, $12.65 \pm 0.01 \mathrm{Ma}$, was found by extrapolation from events 3 and 5 at Site 574 . In Hole $667 \mathrm{~A}$, a tail of strongly reduced presence and a duration of about $0.85 \mathrm{~m}$.y. can be seen above the final decline in abundance of $C$. floridanus. No such tail was observed at Site 574. According to Bukry (1973) and Parker et al. (1985), the LO of $C$. floridanus is near the top of Zone $\mathrm{CN} 5 \mathrm{a}$, but it has been reported to occur as high as Zone CN5b (Miller et al., 1985; Roth and Thierstein, 1972). Judging from the data gathered here, the final decline in the abundance of $C$. floridanus provides a better datum level than the LO for correlation between different sections. Used together with the mutual first rise in abundance of $T$. rugosus and $T$. rioensis and the final decline in the abundance of $S$. heteromorphus, the biostratigraphic resolution could be improved for the lower part of the middle Miocene.

The mutual sharp rise in the abundance of $T$. rugosus and T. rioensis could be a useful biostratigraphic marker in the equatorial Atlantic Ocean as well as in the equatorial Pacific Ocean. At Site 574 in the Pacific this event occurs in an interval where the sediment is disturbed by reworking and it is not as distinct as in Hole 667A in the Atlantic. Despite this, it can be determined with quite good precision with the aid of the cumulative percentages of the triquetrorhabdulids. The age for this mutual rise in abundance is estimated to be 12.57 $\pm 0.01 \mathrm{Ma}$, which was obtained by extrapolation from events 3 and 5 at Site 574.

\section{CONCLUSION}

The use of quantitative methods, combined with short sampling intervals, revealed that most of the species investigated show tails of very low abundances below and above their consistent presence. In ODP Hole 667A these tails vary in duration from about $0.1 \mathrm{~m} . \mathrm{y}$. (above the final decline in the abundance of $S$. ciperoensis) up to about $2 \mathrm{~m}$.y. (below the first rise in the abundance of $T$. rugosus). If the abundance pattern of $S$. heteromorphus in Hole 667A and at Site 574 are compared, a tail with a duration of about $1.2 \mathrm{~m}$.y. is observed in Hole 667A, but no such tail is seen at Site 574 if the reoccurrence is omitted. Thus, the final decline in abundance, which is a distinct biostratigraphic signal in both regions, provides a good instrument for correlation of the two sections and to mark the $\mathrm{CN} 4 / \mathrm{CN} 5$ boundary.

The final decline in the abundance of $C$. floridanus provides a good datum in both sections and can be used for correlation. 

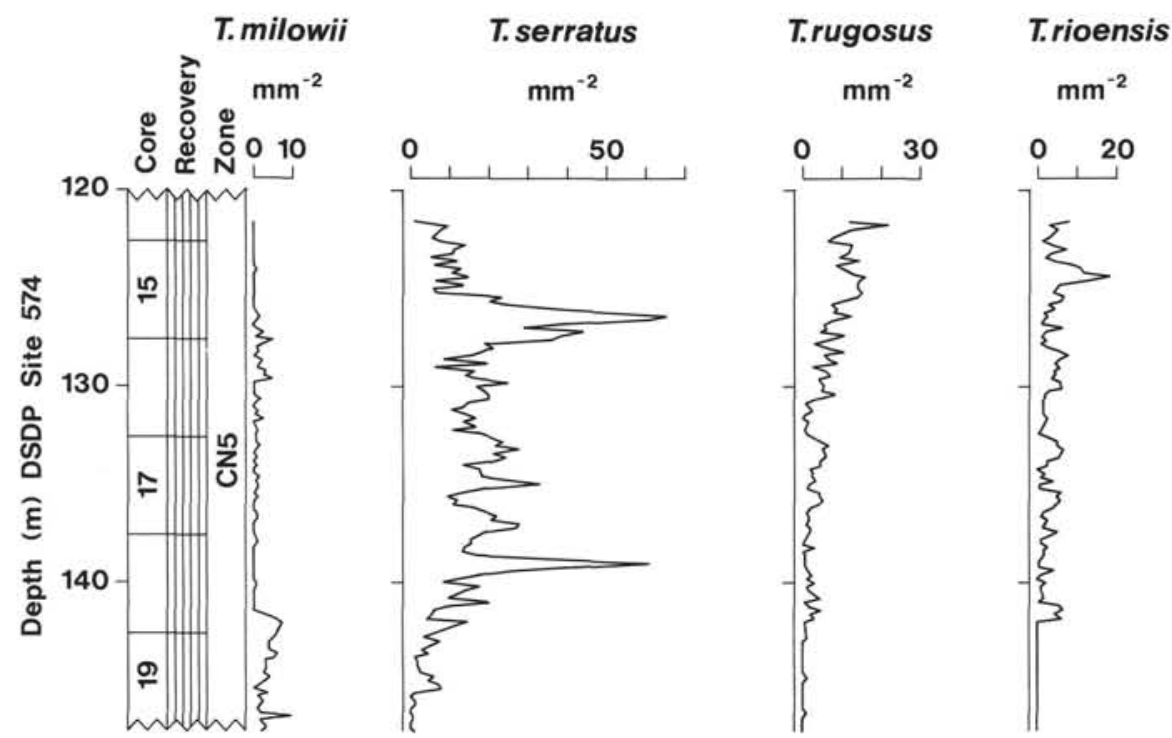

Figure 11. Plots of the abundance patterns of $T$. milowii, $T$. serratus, $T$. rugosus, and $T$. rioensis at Site 574.

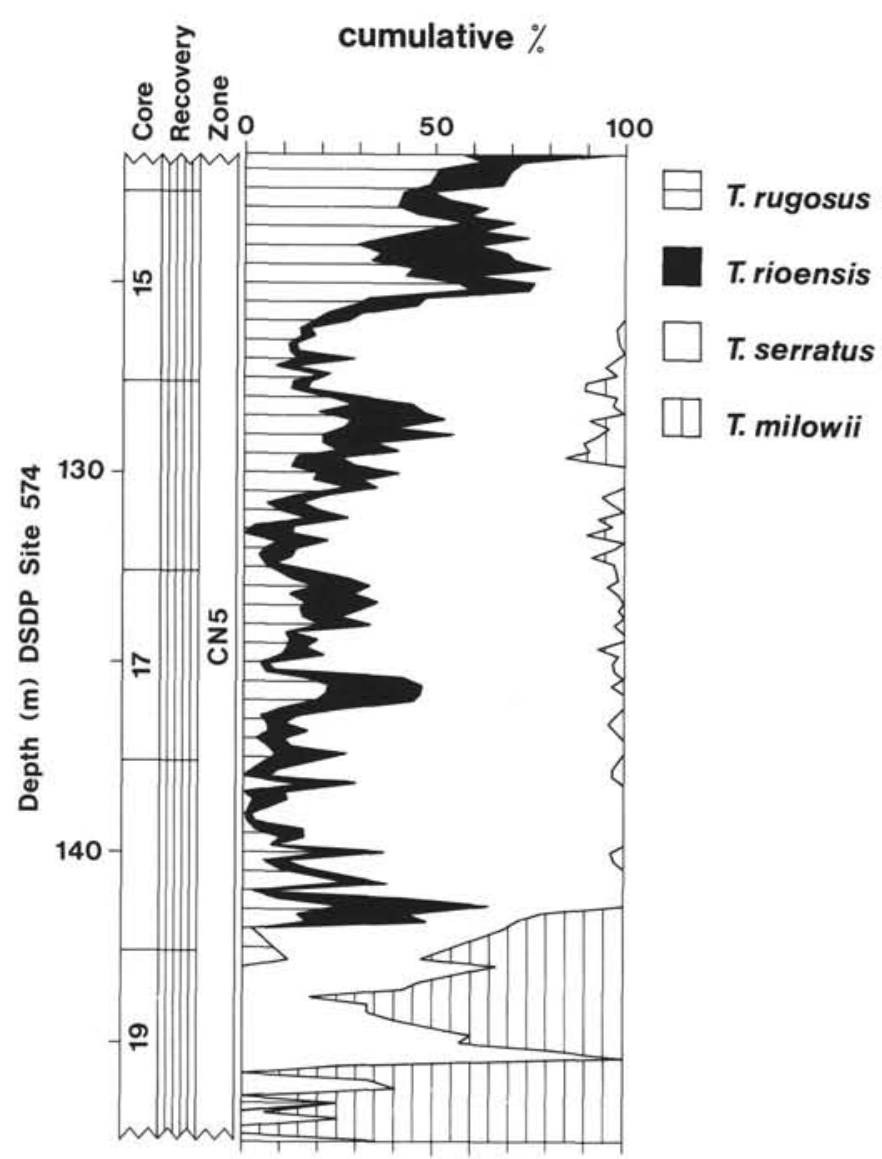

Figure 12. Plots of the cumulative percentages of T. rugosus, T. rioensis, $T$. serratus, and T. milowii at Site 574.

The same applies to the mutual rise in the abundance of $T$. rugosus and $T$. rioensis. These examples show, when correlating two sections, the use of the first sharp rise or the final sharp decline in the abundance of index fossils is likely to give more consistent information than the use of absolute FOs and LOs.

In Hole 667A, it is preferable to use the sharp rise in the abundance of $S$. heteromorphus to mark the $\mathrm{CN} 3 / \mathrm{CN} 4$ boundary rather than its absolute FO. Combined with the final decline in the abundance of $S$. belemnos, it could be possible to increase the biostratigraphic resolution, although this needs further investigation in other sections. The FO of C. macintyrei cannot be used to mark the $\mathrm{CN} 3 / \mathrm{CN} 4$ boundary, as proposed by Bukry (1975, 1978). Instead, Bukry's (1973) original definition of this boundary can be used, provided that $H$. ampliaperta is present.

The age estimates assigned to the different nannofossil events should be regarded as preliminary. In order to minimize the uncertainty of the age estimates, the nannofossil events need to be analyzed in sections with established magnetostratigraphy and with little or no postdepositional mixing of the sediment.

\section{ACKNOWLEDGMENTS}

I thank J. Backman for his help and support with this project. I thank the ODP Leg 108 Shipboard Scientific Party for the permission to use the material from Hole 667A. The samples from Hole 574 were provided by ODP. Financial support was given by the University of Stockholm.

\section{NOTES ON TAXONOMY}

Genus CYCLICARGOLITHUS Bukry, 1971

Cyclicargolithus floridanus (Roth and Hay), Bukry, 1971 (Plate 1, Fig. 1)

Coccolithus floridanus Roth and Hay in Hay et al., 1967, p. 445, pl. 6, figs. 1-4.

Cyclococcolithus neogammation Bramlette and Wilcoxon, 1967, p. 104 , pl. 1 , figs. $1-3$, pl. 4 , figs. $3-5$.

Cyclococcolithus floridanus (Roth and Hay), Müller, 1970a, p. 113, pl. 2, figs. 1-3.

Cyclococcolithus floridanus (Roth and Hay), Roth, 1970, p. 854, pl. 5, fig. 6 .

Cyclicargolithus floridanus (Roth and Hay), Bukry, 1971, p. 312.

Cyclococcolithina floridana (Roth and Hay), Roth and Thierstein, 1972 , p. 436.

Reticulofenestra floridana (Roth and Hay), Theodoridis, 1984, p. 85, pl. 5 , fig. 8. 


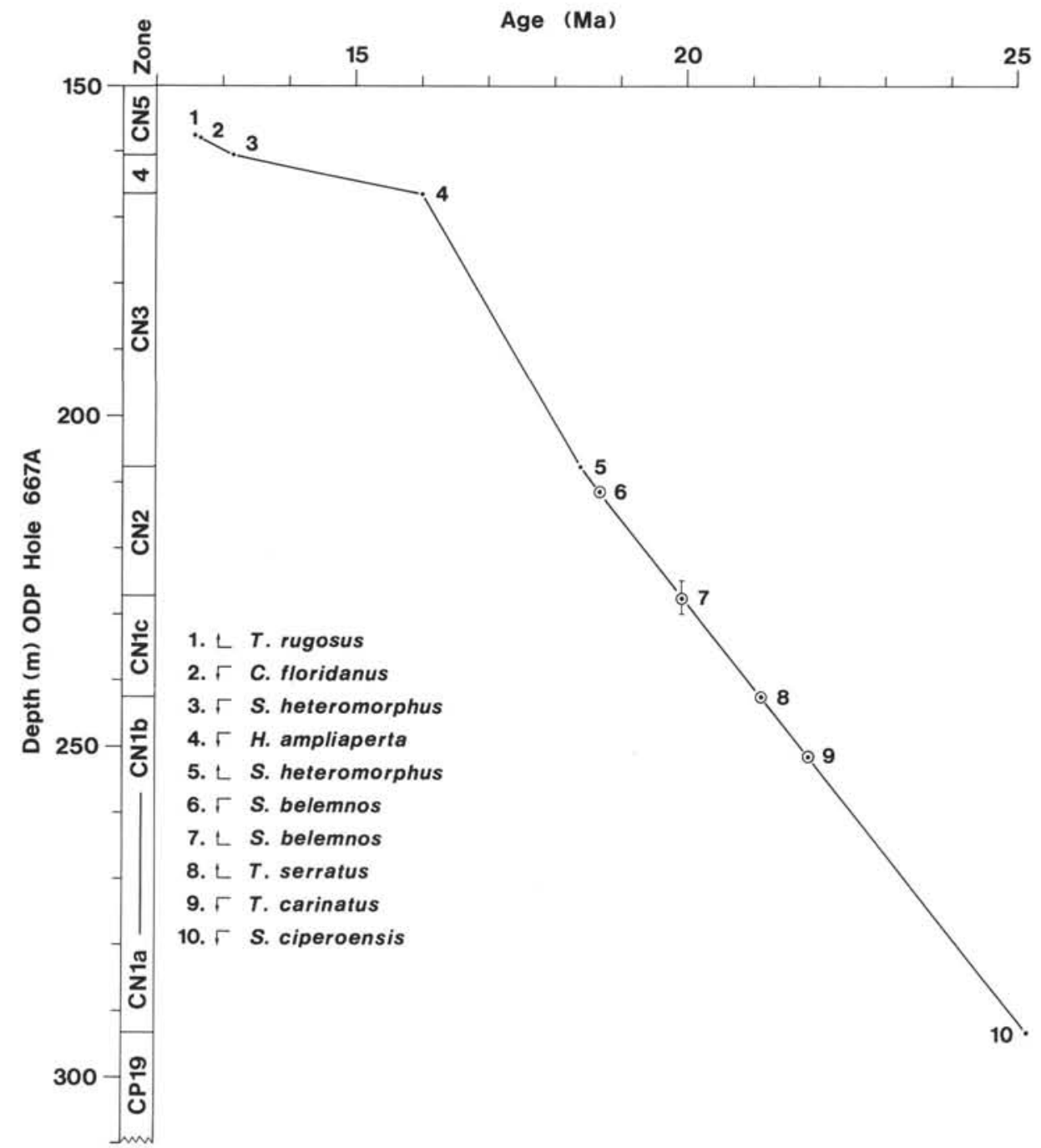

Figure 13. Age/depth plot of the uppermost Oligocene through middle Miocene in ODP Hole 667A in the equatorial Atlantic Ocean based on nannofossil events gathered in this study. The age estimates of the events are obtained by correlating the nannofossil events of Site 608 in the North Atlantic Ocean (Takayama and Sato, 1987) to the magnetostratigraphy of the same site (Clement and Robinson, 1987). Circled events refer to those with interpolated age estimates. The age estimates of events 1 and 2 are obtained by extrapolation using events 3 and 5 at DSDP Site 574 . The nannofossil events together with their age assignments are summarized in Table 1.

Remarks. Cyclicargolithus floridanus is a nearly circular placolith ranging in size from 5 to $10 \mu \mathrm{m}$ in diameter and with a small central opening. When viewed in cross-polarized light, it shows a distinct extinction pattern. It is virtually impossible to distinguish $C$. floridanus from Cyclicargolithus abisectus by the original descriptions of the two species. They both show the same optical behavior and their sizes overlap considerably. The original definition of Coccolithus floridanus describes an elliptic placolith that varies in size from 3.6 to $5 \mu \mathrm{m}$ (Roth and Hay in Hay et al., 1967). Bramlette and Wilcoxon (1967) described Cyclococcolithus neogammation as a circular placolith with a diameter varying from 6 to $12 \mu \mathrm{m}$. Both these forms were described from upper Oligocene strata. Müller (1970a) combined these two forms together with the Eocene form Coccolithus marismontium (Black, 1964) into Cyclococcolithus floridanus referring to a circular form $5-10 \mu \mathrm{m}$ in diameter.

The original definition of Coccolithus abisectus describes a circular to weakly elliptic placolith ranging in size from 8.5 to $11 \mu \mathrm{m}$ (Müller, 1970b). Bukry and Percival (1971) placed this species in the genus Dictyococcites Black (1967), referring to a circular to subcircular placolith ranging in size from 12 to $16 \mu \mathrm{m}$. Bukry (1971) introduced the genus Cyclicargolithus as "circular to subcircular placoliths constructed of two shields connected by a central tube that may be closed or open" and assigned C. floridanus to this genus. Wise (1973) transferred C. abisectus to the genus Cyclicargolithus because in cross-polarized light it resembles C. floridanus. Theodoridis (1984) assigned these two forms to the genus Reticulofenestra Hay et al. (1966), arguing that Cyclicargolithus is a junior synonym of Reticulofenestra. In their original definition of the genus Reticulofenestra, Hay et al. (1966) described "placoliths with a large central opening spanned by a reticular or lacy net." The central opening is commonly one-third or more of the diameter of the entire fossil, and the reticular net in the central opening is very seldom preserved (e.g., Backman, 1980). Considering the lack of a "large central opening," it is not desirable to refer $C$. floridanus and $C$. abisectus to the genus Reticulofenestra.

Genus HELICOSPHAERA Kamptner, 1954

Helicosphaera ampliaperta Bramlette and Wilcoxon, 1967 (Plate 1, Fig. 2)

Helicosphaera ampliaperta Bramlette and Wilcoxon, 1967, p. 105, pl. 6, figs. 1-4. 


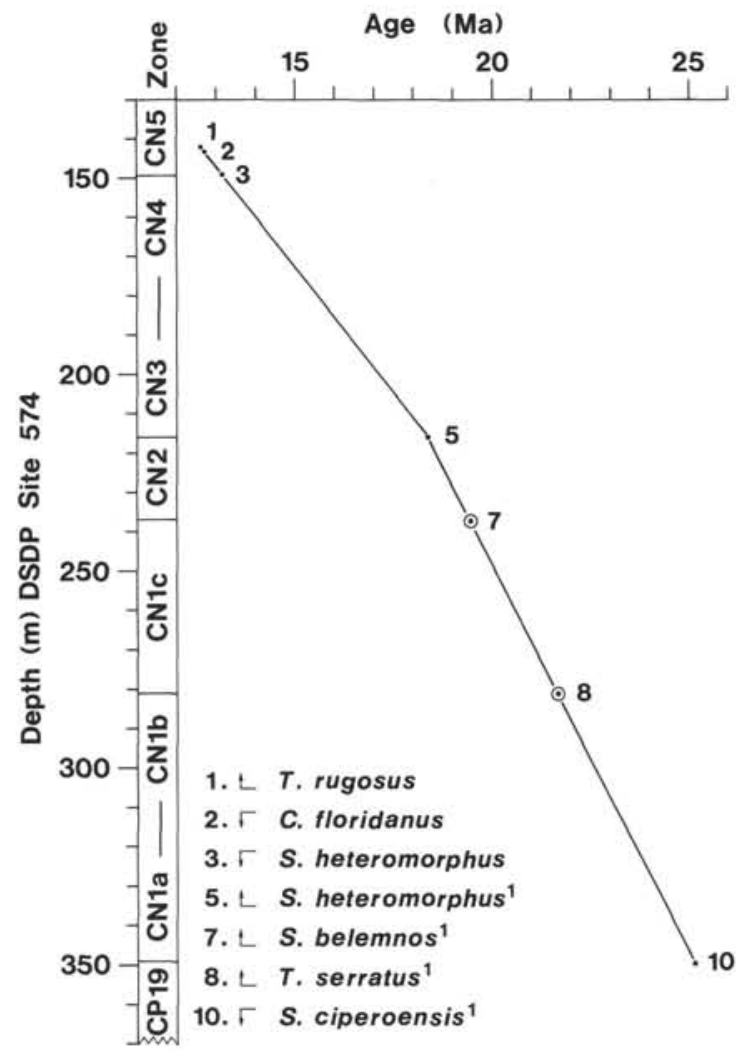

Figure 14. Age/depth plot of the uppermost Oligocene through middle Miocene at DSDP Site 574 in the equatorial Pacific Ocean. The plot is partly based on the nannofossil events gathered in this study and partly on the work of Pujos (1985). The age estimates are obtained in the same way as for Hole 667A. The circled event refers to one with an interpolated age estimate. Superfix 1 represents depth data from Pujos. The nannofossil events and their age assignments are summarized in Table 2.

Table 1. Summary of lower to middle Miocene datums investigated in ODP Hole 667A and their age estimates.

\begin{tabular}{|c|c|c|c|}
\hline $\begin{array}{l}\text { Biostratigraphic } \\
\text { events }\end{array}$ & $\begin{array}{c}\text { Zonal } \\
\text { boundary }\end{array}$ & $\begin{array}{l}\text { Depth } \\
\text { (mbsf) }\end{array}$ & $\begin{array}{l}\text { Age } \\
\text { (Ma) }\end{array}$ \\
\hline (1) $九 T$, rugosus & - & $157.80 \pm 0.15$ & $\mathrm{a}_{12.57 \pm 0.01}$ \\
\hline (2) $\leftarrow$ C. floridanus & - & $158.10 \pm 0.15$ & $\mathrm{a}_{12.65} \pm 0.01$ \\
\hline (3) $\leftarrow S$. heteromorphus & $\mathrm{N} 4 / \mathrm{CN} 5$ & $160.65 \pm 0.30$ & $b_{13.17} \pm 0.03$ \\
\hline (4) $\curvearrowleft$ H. ampliaperta & $\mathrm{CN} 3 / \mathrm{CN} 4$ & $166.40 \pm 0.15$ & $b_{16.01} \pm 0.12$ \\
\hline (5) $2 S$, heteromorphus & $\mathrm{CN} 2 / \mathrm{CN} 3$ & $207.85 \pm 0.15$ & $\mathrm{~b}_{18.42} \pm 0.15$ \\
\hline (6) $\leftarrow S$. belemnos & - & $211.50 \pm 0.15$ & $c_{18.71} \pm 0.01$ \\
\hline (7) 2 S, belemnos & $\mathrm{CN} 1 / \overline{C N} 2$ & $227.25 \pm 2.50$ & $c_{19.96} \pm 0.20$ \\
\hline$(8)^{\imath} T$. serratus & $\mathrm{CN} 1 \mathrm{~b} / \mathrm{CN} / \mathrm{c}$ & $242.40 \pm 0.15$ & $c_{1.16} \pm 0.01$ \\
\hline $\mathrm{d}_{(9)}-T$. carinatus & - & $251.60 \pm 0.15$ & $c_{21} .89 \pm 0.01$ \\
\hline (10) $-S$. ciperoensis & $\mathrm{CP} 19 / \mathrm{CN} 1$ & $293.20 \pm 0.15$ & $\mathrm{e}_{25.2}$ \\
\hline
\end{tabular}

a Ages obtained by extrapolation using events 3 and 5 at DSDP Site 574 .

b Ages obtained by correlating the nannofossil events at DSDP Site 608

(Takayama and Sato, 1987) to the magnetostratigraphy of the same site (Clement and Robinson, 1987).

c Age obtained by interpolation between events 5 and 10 .

d Sharp decline in abundance of $T$. carinatus.

${ }^{\mathrm{e}}$ Age estimate from Berggren et al., 1985.

Helicopontosphaera ampliaperta (Bramlette and Wilcoxon) Hay, 1970, p. 458.

Remarks. Helicosphaera ampliaperta ranges in size from 7 to 12 $\mu \mathrm{m}$ in length and is robust with a relatively large central opening. It has a reduced terminal flange on the distal shield, although some individuals have this terminal flange extended. Müller (1981) recorded a smaller $(5-6 \mu \mathrm{m})$ and less robust variety of $H$. ampliaperta and referred to it as Helicosphaera cf. ampliaperta. No such morphotype was recorded with certainty in Hole 667A.

\section{Genus SPHENOLITHUS Deflandre, 1952}

Remarks. The species Sphenolithus belemnos Bramlette and Wilcoxon, 1967 (pl. 1, fig. 4), Sphenolithus ciperoensis, Bramlette and Wilcoxon, 1967 (Plate 1, Fig. 3), and Sphenolithus heteromorphus, Deflandre, 1953 (pl. 1, fig. 5) are all used as marker species. They are easily distinguished from other sphenoliths and from each other by their different optical pattern when viewed in cross-polarized light.

\section{Sphenolithus sp. 1 \\ (Plate 1, Fig. 6)}

Remarks. Sphenolithus sp. 1 ranges in size from 6 to $9 \mu \mathrm{m}$ in length and 4.5 to $6.5 \mu \mathrm{m}$ at the widest part of the base. The apical spine of Sphenolithus sp. 1 is made of one single crystal, whereas the basal part is made of two circles of spines. The lower circle consists of 10-12 relatively large tabular-formed spines that are oriented obliquely relative to the length axis. The upper circle is made of much smaller nodelike spines. When viewed in plane-polarized light, the basal part of Sphenolithus sp. 1 is prominent and has the appearance of two large lobes. In cross-polarized light, when oriented parallel to the polarization plane, the appearance is dominated by the large basal part, which seems to be made of four lobes, the two lower being much larger than the two upper. This basal part also shows distinct extinction bands.

The apical spine is extinct when oriented parallel to the polarization plane. When oriented $45^{\circ}$ to the polarization plane, the apical spine is bright, whereas the basal part becomes grayish and loses its distinct extinction bands. Sphenolithus $\mathrm{sp} .1$ is larger than the middle Eocene form Sphenolithus spiniger Bukry (1971;5-6 $\mu \mathrm{m})$, which it otherwise closely resembles. It is easily distinguished from Sphenolithus heteromorphus, with which it co-occurs, by its more prominent and larger basal part and different optical appearance of the same part when viewed in cross-polarized light. Sphenolithus sp. 1 was found only in Samples 108-667A-21H-6, 75-76 cm, and 108-667A-21H-6, $108-109 \mathrm{~cm}$, which are assigned to the lower Miocene Zone CN3.

\section{Genus TRIQUETRORHABDULUS Martini, 1965 Triquetrorhabdulus carinatus Martini, 1965}

(Plate 1, Fig. 7)

Remarks. Triquetrorhabdulus carinatus is an elongated form with both ends tapering. When viewed in cross-polarized light, it shows maximum extinction parallel to the polarization plane. The median ridge is often obscured by diagenetic overgrowth of calcite. Thus form, length, and optical behavior are used to distinguish it from other triquetrorhabdulids.

\section{Triquetrorhabdulus milowii Bukry, 1971 (Plate 1, Fig. 8)}

Remarks. Triquetrorhabdulus milowii is the shortest and broadest member of the genus Triquetrorhabdulus. It is often slightly curved. When observed in plane-polarized light, oriented parallel to the polarization plane, the blade seen in edge view shows strong relief. This species is distinguished from other members of the genus by its shape and strong birefringence when viewed in cross-polarized light.

$$
\begin{aligned}
& \text { Triquetrorhabdulus rioensis } \mathrm{n} . \mathrm{sp} . \\
& \text { (Plate 1, Figs. 9-10) }
\end{aligned}
$$

Derivation of name. In honor of Professor Domenico Rio, University of Parma.

Diagnosis. A blade-shaped species of the genus Triquetrorhabdulus with strong birefringence when viewed in cross-polarized light.

Description. Triquetrorhabdulus rioensis ranges in size from 13 to $22 \mu \mathrm{m}$. It is elongated and blade shaped, often with one end slightly more pointed than the other. When viewed in plane-polarized light, it shows its highest relief when oriented $90^{\circ}$ to the polarization plane. When viewed in cross-polarized light, it shows strong birefringence with maximum extinction nearly parallel to the polarization plane.

Remarks. Triquetrorhabdulus rioensis has a morphology that is virtually identical to that of $T$. rugosus, making them impossible to separate in the scanning electron microscope. In the light microscope they are easily distinguished by the strong birefringence of $T$. rioensis 
Table 2. Summary of lower to middle Miocene datums investigated at DSDP Site 574 and their age estimates.

\begin{tabular}{|c|c|c|c|c|}
\hline & $\begin{array}{l}\text { Biostratigraphic } \\
\text { events }\end{array}$ & $\begin{array}{c}\text { Zonal } \\
\text { boundary }\end{array}$ & $\begin{array}{l}\text { Depth } \\
\text { (mbsf) }\end{array}$ & $\begin{array}{l}\text { Age } \\
\text { (Ma) }\end{array}$ \\
\hline (1) & T. rugosus & - & $141.90 \pm 0.10$ & ${ }^{a} 12.57 \pm 0.01$ \\
\hline (2) & C. floridanus & - & $142.90 \pm 0.10$ & $a_{12.65} \pm 0.01$ \\
\hline (3) & S. heteromorphus & $\mathrm{CN} 4 / \mathrm{CN} 5$ & $149.50 \pm 0.10$ & $b_{13.17} \pm 0.03$ \\
\hline (5) & S. heteromorphus & $\mathrm{CN} 2 / \mathrm{CN} 3$ & $c_{216.25} \pm 0.75$ & $b_{18.42} \pm 0.15$ \\
\hline (7) & $S$. belemnos & $\mathrm{CN} 1 / \mathrm{CN} 2$ & $c_{236.75} \pm 0.75$ & $d_{19.46} \pm 0.04$ \\
\hline (8) & T. serratus & $\mathrm{CNIb} / \mathrm{CN} / \mathrm{c}$ & $c_{281.25} \pm 0.75$ & $\mathrm{~d}_{21.73 \pm 0.04}$ \\
\hline (10) & S. ciperoensis & CP19/CN1 & $c_{349.25} \pm 0.75$ & ${ }^{e} 25.2$ \\
\hline
\end{tabular}

${ }^{\text {a }}$ Ages obtained by extrapolation using events 3 and 5 .

b Ages obtained by correlating the nannofossil events at DSDP Site 608 (Takayama and Sato, 1987) to the magnetostratigraphy (Clement and Robinson, 1987) of the same site.

c Depth data from Pujos, 1985.

d Age obtained by interpolation between events 7 and 10 .

e Age estimate from Berggren et al., 1985.

Table 3. Comparison of mean sedimentation rates at Sites 667 and 574. The intervals marked are those between the species events in Table 1 and Table 2.

\begin{tabular}{|c|c|c|c|}
\hline \multicolumn{2}{|c|}{ Site 667} & \multicolumn{2}{|r|}{ Site 574} \\
\hline Interval & $\begin{array}{l}\text { Sedimentation rate } \\
(\mathrm{m} / \mathrm{m} . \mathrm{y} .)\end{array}$ & Interval & $\begin{array}{l}\text { Sedimentation rate } \\
(\mathrm{m} / \mathrm{m} . \mathrm{y} .)\end{array}$ \\
\hline $1-2$ & 3.75 & $1-5$ & 12.71 \\
\hline $2-3$ & 4.90 & $5-10$ & 19.62 \\
\hline $3-4$ & 2.02 & & \\
\hline $4-5$ & 17.20 & & \\
\hline $5-10$ & 12.59 & & \\
\hline (1) & osus & (4) & H. ampliaperta \\
\hline (2) & ridanus & (5) & $S$. heteromorphus \\
\hline (3) & eromorphus & (10) & S. ciperoensis \\
\hline
\end{tabular}

when viewed in cross-polarized light. When viewed in plane-polarized light, $T$. rioensis shows marked changes in relief when rotated $90^{\circ}$ from the polarization plane, an orientation in which it shows the highest relief. Similar behavior has been reported for T. milowii (Bukry, 1971) and other triquetrorhabdulids (Aubry, 1988). Both $T$. rioensis and $T$. rugosus show signs of calcite overgrowth, and the difference, both in relief and birefringence, cannot be explained only by this. Rather, it is a phenomena caused by differences in crystal orientation in the two species.

Occurrences. In ODP Hole 667A Triquetrorhabdulus rioensis has its FO in Sample 108-667A-19H-2, 105-106 cm (165.40 mbsf), and shows a sharp rise in abundance at $157.7 \mathrm{~m}$ (Fig. 7). At DSDP Site 574 its FO is in Sample 85-574-18H-3, 119-121 cm (141.80 mbsf), but no sharp rise in abundance can be seen there. Triquetrorhabdulus rioensis co-occurs with $T$. rugosus both in Hole 667A and at Site 574 . Furthermore, $T$. rioensis has been observed at DSDP Site 608 and ODP Holes 714A and 714B.

Holotype. Plate 1, Figs. 9-10, Sample 108-667A-18H-2, 75-76 cm.

Size. Length: $18 \mu \mathrm{m}$. Width: $3.8 \mu \mathrm{m}$.

Type locality and type level. ODP Hole 667A, Sample 108-667A$18 \mathrm{H}-2,75-76 \mathrm{~cm}$, lower middle Miocene.

Triquetrorhabdulus rugosus Bramlette and Wilcoxon, 1967 (Plate 1, Fig. 11)

Remarks. Triquetrorhabdulus rugosus is elongated in outline and often more pointed at one end. It is weakly birefringent when viewed in cross-polarized light and shows maximum extinction $10^{\circ}-15^{\circ}$ from the polarization plane. It is distinguished from other triquetrorhabdulids by its low birefringence and its rugose appearance and high relief when viewed in plane-polarized light. Triquetrorhabdulus rugosus has its $\mathrm{FO}$ in Core 108-667A-18H. In the equatorial Pacific it has its FO in Core $85-574-17 \mathrm{H}$. The abundance of $T$. rugosus is much higher in the equatorial Atlantic than the equatorial Pacific, as is the case with $T$. rioensis.

Triquetrorhabdulus serratus (Bramlette and Wilcoxon) n.comb. (Plate 1, Fig. 12)

Triquetrorhabdulus sp. Martini, 1965, p. 408, pl. 36, figs. 4-6. Orthorhabdus serratus Bramlette and Wilcoxon, 1967, p. 114, pl. 9 , figs. $5-10$.

Triquetrorhabdulus martinii Gartner, 1967, p. 6, pl. 10, figs. 1a-c, $2 \mathrm{a}-\mathrm{c}$, and $3 \mathrm{a}-\mathrm{b}$.

Rhabdothorax serratus (Bramlette and Wilcoxon), Roth, 1970, p. 807. Triquetrorhabdulus martinii (Gartner), Theodoridis, 1984, p. 90, pl. 10 , figs. 11-16.

Remarks. The fine structure of the broader end of $T$. serratus is often obscured by diagenetic calcite overgrowth. When viewed in plane-polarized light, this species shows its highest relief at $90^{\circ}$ to the polarization plane. It is strongly birefringent in cross-polarized light and shows maximum extinction almost parallel to the polarization plane. Triquetrorhabdulus serratus is distinguished from other members of the genus Triquetrorhabdulus not only by its form but also its optical behavior in plane-polarized light. In his original definition of Triquetrorhabdulus sp., Martini (1965) described a $12-22-\mu \mathrm{m}$-long form consisting of three calcite rods and having one end slightly truncated, showing maximum extinction parallel to the polarization plane. Bramlette and Wilcoxon (1967) described a 10-20- $\mu \mathrm{m}$-long, three-edged rod with one pointed end and the other larger and often concave. Gartner (1967) described a calcite rod, varying in size and shape, tapered at one end and the other as irregularly knobby.

Roth (1970) recombined the above-mentioned forms into Rhabdothorax serratus (Bramlette and Wilcoxon). Rhabdothorax is a genus introduced by Kamptner (1958) used to describe egg-shaped to spherical coccospheres with coccoliths that have a polygonal basal part and a stavelike central protrusion. The type species of this genus is Rhabdothorax erinaceus (ex. Rhabdosphaera). The members of the genus Rhabdothorax are distinguished from the members of the genus Rhabdosphaera by the round basal part of the coccoliths in the latter. Triquetrorhabdulus martinii is considered to be a junior synonym of T. serratus. Triquetrorhabdulus serratus has its FO in Core 108667A-27X, which marks the top of Zone CN1b. It occurs sporadically up to Core 108-667A-18H, which is the highest core investigated from the equatorial Atlantic. In the equatorial Pacific, $T$. serratus occurs consistently but in low abundance throughout the interval of Site 574 where the triquetrorhabdulids were investigated.

\section{REFERENCES}

Aubry, M.-P., 1988. Handbook of Cenozoic Calcareous Nannoplankton, Book 2: Ortholithae (Catinasters, Ceratoliths, Rhabdoliths): New York (Micropaleontology Press). 
Backman, J., 1980. Miocene-Pliocene nannofossils and sedimentation rates in the Hatton-Rockall basin, northeast Atlantic Ocean. Stockholm Contrib. Geol., 36:1-91.

, 1986a. Accumulation patterns of Tertiary calcareous nannofossils around extinctions. Geol. Rundsch., 75:185-196. 1986b. Late Paleocene to middle Eocene calcareous nannofossil biochronology from the Shatsky Rise, Walvis Ridge and Italy. Palaeogeogr., Palaeoclimatol., Palaeoecol., 57:43-59.

Backman, J., and Shackleton, N. J., 1983: Quantitative biochronology of Pliocene and early Pleistocene calcareous nannofossils from the Atlantic, Indian and Pacific oceans. Mar. Micropaleontol., 8:141-170.

Berggren, W. A., Kent, D. V., and Flynn, J. J., 1985. Jurassic to Paleogene: Part 2, Paleogene geochronology and chronostratigraphy. In Snelling, N. J. (Ed.), The Chronology of the Geological Record. Geol. Soc. Mem. (London), 10:141-195.

Black, M., 1964. Cretaceous and tertiary coccoliths from Atlantic seamounts. Palaeontology, 7:306-316.

1967. New names for some coccolith taxa. Geol. Soc. Spec. Pap. (London), 1640:134-145.

Bramlette, M. N., and Wilcoxon, J. A., 1967. Middle Tertiary calcareous nannoplankton of the Cipero section, Trinidad, W.I. Tulane Stud. Geol., 5:93-131.

Bukry, D., 1971. Cenozoic calcareous nannofossils from the Pacific Ocean. Trans. San Diego Soc. Nat. Hist., 16:303-328.

1972. Coccolith stratigraphy-Leg 14, Deep Sea Drilling Project. In Hayes, D. E., Pimm, A. C., et al., Init. Repts. DSDP, 14: Washington (U.S. Govt. Printing Office), 487-494.

1973. Low-latitude coccolith biostratigraphic zonation. In Edgar, N. T., Saunders, J. B., et al., Init. Repts. DSDP, 15: Washington (U.S. Govt. Printing Office), 685-703.

1975. Coccolith and silicoflagellate stratigraphy, northwestern Pacific Ocean, Deep Sea Drilling Project Leg 32. In Larson, R. L., Moberly, R., et al., Init. Repts. DSDP, 32: Washington (U.S. Govt. Printing Office), 677-701.

1978. Biostratigraphy of Cenozoic marine sediment by calcareous nannofossils. Micropaleontology, 24:44-60.

Bukry, D., and Percival, S. F., 1971. New Tertiary calcareous nannofossils. Tulane Stud. Geol. Paleontol., 8:123-146.

Clement, B. M., and Robinson, F., 1987. The magnetostratigraphy of Leg 94 sediments. In Ruddiman, W. F., Kidd, R. B., Thomas, E., et al., Init. Repts. DSDP, 94, Pt. 2: Washington (U.S. Govt. Printing Office), 635-650.

Deflandre, G., 1952. Classe des Coccolithophoridés (Coccolithophoridae Lohman, 1902). In Grassé, P. P. (Ed.), Traité de zoologie: Paris (Masson), 439-470.

1953. Héterogénité intrinsèque et pluralité des éléments dans les coccolithes actuels et fossiles. C. R. Acad. Sci. Paris, Ser. 2, 237:1785-1787.

Gartner, S., Jr., 1967. Calcareous nannofossils from Neogene of Trinidad, Jamaica, and Gulf of Mexico. Univ. Kans. Paleontol. Contrib. Pap., 29:1-7.

Haq, B. U., and Lohmann, G. P., 1976. Early Cenozoic calcareous nannoplankton biogeography of the Atlantic Ocean. Mar. Micropaleontol., 1:119-194.

Hay, W. W., 1970. Calcareous nannofossils from cores recovered on Leg 4. In Bader, R. G., Gerard, R. D., et al., Init. Repts. DSDP, 4: Washington (U.S. Govt. Printing Office), 455-501.

Hay, W. W., Mohler, H. P., Roth, P. H., Schmidt, R. R., and Boudreaux, J. E., 1967. Calcareous nannoplankton zonation of the Cenozoic of the Gulf Coast and Caribbean-Antillean area and transoceanic correlation. Trans. Gulf Coast Assoc. Geol. Soc., 17:428-459.

Hay, W. W., Mohler, H., and Wade, M. E., 1966. Calcareous nannofossils from Nal'chik (northwest Caucasus). Eclogae Geol. Helv., 59:379-399.

Kamptner, E., 1954. Unteruchungen über den Feinbau der Coccolithen. Arch. Protistenkd., 100:1-90.

1958. Betrachtungen zur Systematik der Kalkflagellaten, nebst Versuch einer Gruppierung der Chrysomonadales. Arch. Protistenkd., 103:54-116.
Lohman, W. H., 1986. Calcareous nannoplankton biostratigraphy of the southern Coral Sea, Tasman Sea, and southwestern Pacific Ocean, Deep Sea Drilling Project Leg 90: Neogene and Quaternary. In Kennett, J. P., van der Borch, C. C., et al., Init. Repts. DSDP, 90, Pt. 2: Washington (U.S. Govt. Printing Office), 763-793.

Martini, E., 1965. Mid-Tertiary calcareous nannoplankton from $\mathrm{Pa}$ cific deep-sea cores. In Whittard, W. F., and Bradshaw, R. B. (Eds.), Submarine Geology and Geophysic. Proc. 17th Symp. Colston Res. Soc.: London (Butterworths), 393-411.

,1971. Standard Tertiary and Quaternary calcareous nannoplankton zonation. In Farinacci, A. (Ed.), Proceedings of the II Planktonic Conference, Roma, 1970: Rome (Ed. Tecnoscienza), 2:739-785.

Shipboard Scientific Party, 1985. Site 574. In Mayer, L., Theyer, F., et al., Init. Repts. DSDP, 85: Washington (U.S. Govt. Printing Office), 225-329.

Miller, K. G., Aubry, M.-P., Khan, M. J., Melillo, A. J., Kent, D. V., and Berggren, W. A., 1985. Oligocene-Miocene biostratigraphy, magnetostratigraphy, and isotopic stratigraphy of the western North Atlantic. Geology, 13:257-261.

Müller, C., 1970a. Nannoplankton-Zonen der Unteren Meeresmolasse Bayerns. Geol. Bavarica, 63:107-117.

1970b. Nannoplankton aus dem Mittel-Oligozän von Norddeutschland und Belgien. Neues. Jahrb. Geol. Palaeontol. Abh., $135: 82-101$

1981. Beschreibung neuer Helicosphaera-Arten aus dem Miozän und Revision biostratigraphischer Reichweiten einiger neogener Nannoplankton-Arten. Senckenbergiana Lethaea, 61: $427-434$.

Okada, H., and Bukry, D., 1980. Supplementary modification and introduction of code numbers to the low-latitude coccolith biostratigraphic zonation (Bukry, 1973; 1975). Mar. Micropaleontol., $5: 321-325$.

Parker, M. E., Clark, M., and Wise, S. W., Jr., 1985. Calcareous nannofossils of Deep Sea Drilling Project Sites 558 and 563, North Atlantic Ocean: biostratigraphy and the distribution of Oligocene braarudosphaerids. In Bougault, H., Cande, S. C., et al., Init. Repts. DSDP, 82: Washington (U.S. Govt. Printing Office), 559-589.

Pujos, A., 1985. Cenozoic nannofossils, central equatorial Pacific, Deep Sea Drilling Project Leg 85. In Mayer, L., Theyer, F., et al., Init. Repts. DSDP, 85: Washington (U.S. Govt. Printing Office), 581-607.

Roth, P. H., 1970. Oligocene calcareous nannoplankton biostratigraphy. Eclogae Geol. Helv., 63:799-881.

Roth, P. H., and Thierstein, H. R., 1972. Calcareous nannoplankton: Leg 14 of the Deep Sea Drilling Project. In Hayes, D. E., Pimm, A. C., et al., Init. Repts. DSDP, 14: Washington (U.S. Govt. Printing Office), 421-485.

Shipboard Scientific Party, 1988. Site 667. In Ruddiman, W., Sarnthein, M., et al., Proc. ODP, Init. Repts, 108, Sect. 2: College Station, TX (Ocean Drilling Program), 833-930.

Takayama, T., and Sato, T., 1987. Coccolith biostratigraphy of the North Atlantic Ocean, Deep Sea Drilling Project Leg 94. In Ruddiman, W. F., Kidd, R. B., Thomas, E., et al., Init. Repts. DSDP, 94, Pt. 2: Washington (U.S. Govt. Printing Office), $651-702$.

Theodoridis, S., 1984. Calcareous nannofossil biozonation of the Miocene and revision of the helicoliths and discoasters. Utrecht Micropaleontol. Bull, 32:1-271.

Wise, S. W., Jr., 1973. Calcareous nannofossils from cores recovered during Leg 18, Deep Sea Drilling Project: biostratigraphy and observations of diagenesis. In Kulm, L. D., von Huene, R., et al., Init. Repts. DSDP, 18: Washington (U.S. Govt. Printing Office), 569-615.

Date of initial receipt: 4 May 1988

Date of acceptance: 17 October 1988

Ms 108B-121 


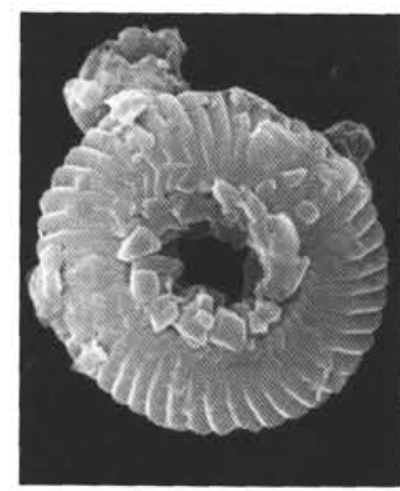

1

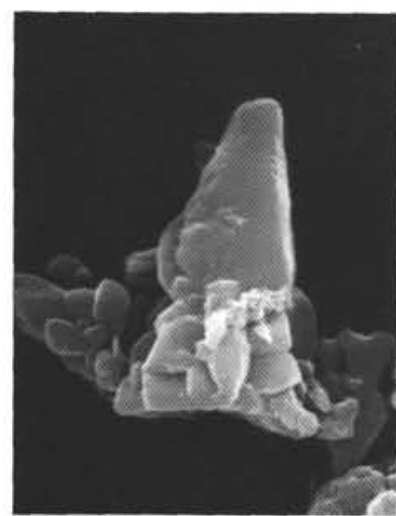

5

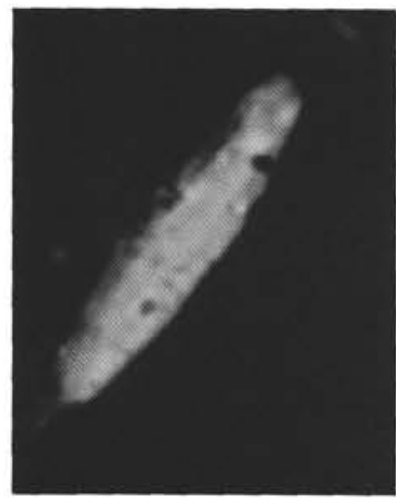

9

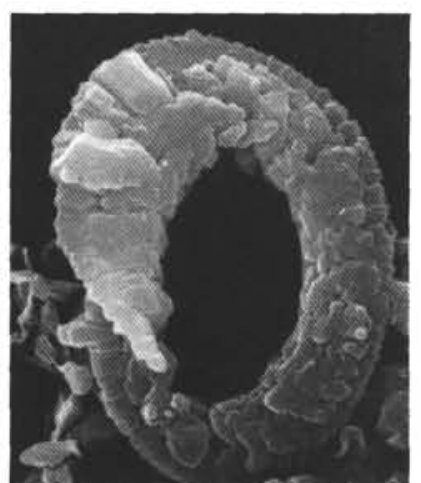

2

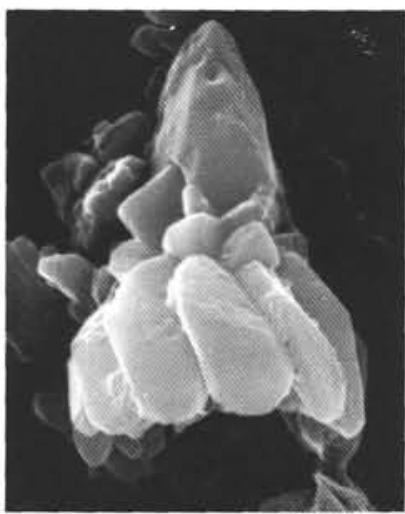

6

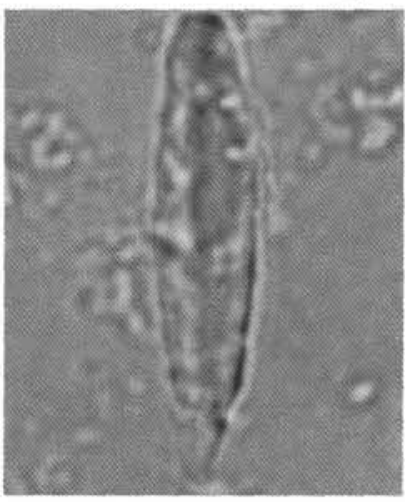

10
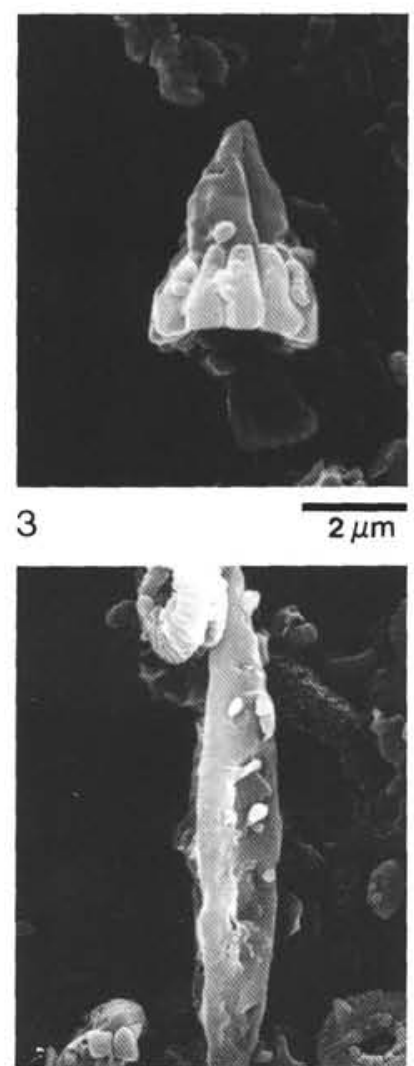

$2 \mu \mathrm{m}$

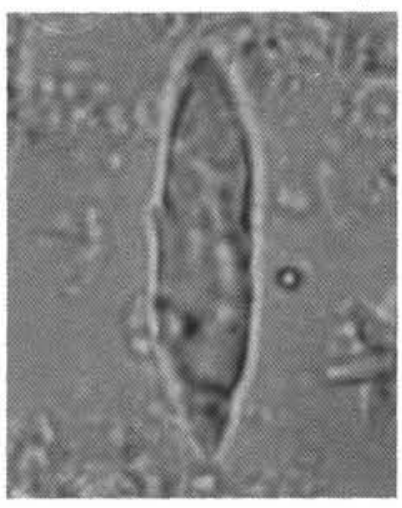

11

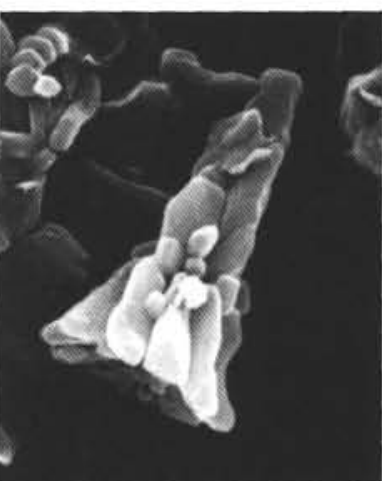

4

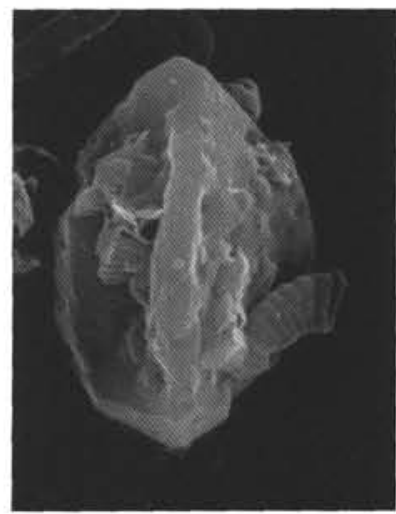

8

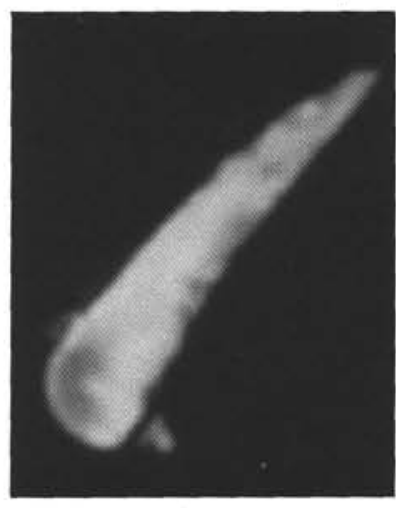

12

$2 \mu \mathrm{m}$

Plate 1. 1. Cyclicargolithus floridanus (Roth and Hay), Bukry, 1971. Sample 108-667A-22H-3, 75-76 cm. 2. Helicosphaera ampliaperta Bramlette and Wilcoxon, 1967. Sample 108-667A-22H-3, 75-76 cm. 3. Sphenolithus ciperoensis Bramlette and Wilcoxon, 1967. Sample 108-667A-34X-3, 70-71 cm. 4. Sphenolithus belemnos Bramlette and Wilcoxon, 1967. Sample 108-667A-25X-3, 75-76 cm. 5. Sphenolithus heteromorphus Deflandre, 1953. Sample 108-667A-21H-6, 75-76 cm. 6. Sphenolithus sp.1. Sample 108-667A-21H-6, 75-76 $\mathrm{cm}$. 7. Triquetrorhabdulus carinatus Martini, 1965. Sample 108-667A-29X-3, 75-76 cm. 8. Triquetrorhabdulus milowii Bukry, 1971. Sample 108-667A-19H-3, 75-76 cm. 9-10. Triquetrorhabdulus rioensis, holotype. (9) Cross-polarized light, $45^{\circ}$ to the polarization plane. Sample $108-667 \mathrm{~A}-18 \mathrm{H}-2,75-76 \mathrm{~cm}$. (10) Plane-polarized light, $90^{\circ}$ to the polarization plane. 11. Triquetrorhabdulus rugosus Bramlette and Wilcoxon, 1967. Plane-polarized light, Sample 108-667A-18H-1, 75-76 cm. 12. Triquetrorhabdulus serratus Bramlette and Wilcoxon, 1967. Sample 108-667A-26X-3, 75-76 cm, cross-polarized light. 